\title{
Modification of an atypical clathrin-independent AP-2 adaptin complex of Plasmodium falciparum reduces susceptibility to artemisinin
}

\author{
Ryan C. Henrici ${ }^{1}$; Rachel L. Edwards ${ }^{2+}$; Martin Zoltner $^{3+}$; Donelly A. van Schalkwyk ${ }^{1}$;
} Melissa N. Hart ${ }^{1,4}$; Franziska Mohring ${ }^{1}$; Robert W. Moon ${ }^{1}$; Stephanie D. Nofal ${ }^{5}$; Avnish Patel $^{5}$; Christian Flueck ${ }^{5}$; David A. Baker ${ }^{5}$; Audrey Odom Johnn ${ }^{2}$; Mark C. Field ${ }^{3}$; Colin J. Sutherland ${ }^{1,7^{*}}$

\section{Author Affiliations:}

1 Department of Immunology and Infection, Faculty of Infectious Diseases, London School of Hygiene and Tropical Medicine, London WC1E 7HT, United Kingdom

2 Department of Pediatrics, Washington University St Louis, St Louis, MO, 63110, United States of America

3 School of Life Sciences, University of Dundee, Dow Street, Dundee DD1 4HN, United Kingdom

4 Department of Crystallography, Birkbeck, University of London, London WC1E 7HX, United Kingdom

5 Department of Pathogen Molecular Biology, Faculty of Infectious Diseases, London School of Hygiene and Tropical Medicine, London WC1E 7HT, United Kingdom

6 Department of Molecular Microbiology, Washington University St Louis, St Louis, MO, 63110, United States of America

7 PHE Malaria Reference Laboratory, London School of Hygiene and Tropical Medicine, London WC1E 7HT, United Kingdom

\footnotetext{
${ }^{\dagger}$ Authors contributed equally

* Corresponding author:

Colin J. Sutherland

Department of Immunology and Infection

London School of Hygiene and Tropical Medicine

Keppel St

London, WC1E 7HT

United Kingdom
}

Ph: $\quad+44(0) 2079272338$

Email: colin.sutherland@1shtm.ac.uk 
bioRxiv preprint doi: https://doi.org/10.1101/621078; this version posted April 30 2019. The copyright holder for this preprint (which was not certified by peer review) is the author/funder, who has granted bioRxiv a license to display the preprint in perpetuity. It is made available under aCC-BY-NC-ND 4.0 International license.

\section{Summary}

The efficacy of current antimalarial drugs is threatened by reduced susceptibility of Plasmodium falciparum to artemisinin. In the Mekong region this is associated with mutations in the kelch propeller-encoding domain of pfkelch13, but variants of other parasite proteins are also thought to modulate the response to drug. Evidence from human and rodent studies suggests that the $\mu$-subunit of the AP-2 adaptin trafficking complex is one such protein of interest. We generated transgenic Plasmodium falciparum parasites encoding the I592T variant of $p f a p 2 \mu$, orthologous to the I568T mutation associated with in vivo artemisinin resistance in $P$. chabaudi. When exposed to a four-hour pulse of dihydroartemisin in the ring-stage survival assay, two $P$. falciparum clones expressing AP- $2 \mu$ I592T displayed significant and reproducible survival of $8.0 \%$ and $10.3 \%$, respectively, compared to $<2 \%$ for the 3D7 parental line $(\mathrm{P}=0.0011$ for each clone). In immunoprecipitation and localisation studies of HA-tagged AP- $2 \mu$, we identified interacting partners including AP- $2 \alpha, \mathrm{AP}-1 / 2 \beta, \mathrm{AP}-2 \sigma$ and a kelch-domain protein encoded on chromosome 10 of $P$. falciparum, K10. Conditional knockout indicates that the AP-2 trafficking complex in P. falciparum is essential for the fidelity of merozoite biogenesis and membrane organisation in the mature schizont. We also show that while other heterotetrameric AP-complexes and secretory factors interact with clathrin, AP-2 complex subunits do not. Thus, the AP-2 complex may be diverted from a clathrin-dependent endocytic role seen in most eukaryotes into a Plasmodium-specific function. These findings represent striking divergences from eukaryotic dogma and support a role for intracellular traffic in determining artemisinin sensitivity in vitro, confirming the existence of multiple functional routes to reduced ring-stage artemisinin susceptibility. Therefore, the utility of pfkelchl3 variants as resistance markers is unlikely to be universal, and phenotypic surveillance of parasite susceptibility in vivo may be needed to identify threats to our current combination therapies.

Keywords:

Plasmodium falciparum; adaptin trafficking complex; artemisinin susceptibility; 
bioRxiv preprint doi: https://doi.org/10.1101/621078; this version posted April 30,2019. The copyright holder for this preprint (which was not certified by peer review) is the author/funder, who has granted bioRxiv a license to display the preprint in perpetuity. It is made available under aCC-BY-NC-ND 4.0 International license.

\section{INTRODUCTION}

Antimalarial drugs are indispensable components of the global strategy for malaria control and elimination ${ }^{1}$. Clinical treatment failure with artemisinins, drugs characterised by very short serum half-lives in the treated host, has been demonstrated throughout the Greater Mekong subregion ${ }^{2-7}$, and there is some evidence of decreasing effectiveness of artemisinin combination therapies (ACT) in Africa ${ }^{8-12}$. Delayed parasite clearance in Southeast Asia has been linked to several mutations in the propeller-encoding domain of the pfkelch13 (K13) gene ${ }^{6,13}$. However, these mutations have not been observed in parasite populations circulating in Africa, and the function of K13 and its role in resistance remains unclear ${ }^{9,11}$. Other Plasmodium loci have been shown to contribute to artemisinin susceptibility in laboratory studies, including the $P$. falciparum homologue of the actin-binding protein Coronin ${ }^{14}$. Given that variants of at least two different proteins modulate parasite survival under artemisinin pressure, understanding of any genetic and cellular factors that affect artemisinin susceptibility is desirable for preservation of ACT efficacy worldwide.

Among other candidate loci, the medium $(\mu)$ subunit of the AP-2 adaptin trafficking complex $(\mathrm{AP}-2 \mu)$ was first associated with artemisinin susceptibility by Hunt et al in multi-drug resistant lineages of $P$. chabaudi, derived by experimental drug selection in rodent hosts ${ }^{15}$. Linkage analysis identified a mutation encoding PcAP- $2 \mu(\mathrm{I} 568 \mathrm{~T})$ in an artemisinin resistant parasite population when compared with sensitive progenitors ${ }^{16}$. While subsequent studies failed to identify an orthologous $P$. falciparum AP-2 $\mu(\mathrm{I} 592 \mathrm{~T})$ mutation in human infections, evidence was found for directional selection for a PfAP- $2 \mu(\mathrm{S} 160 \mathrm{~N})$ variant in ACT-treated patients ${ }^{9}$. In vitro over-expression suggested this naturally-occurring PfAP- $2 \mu$ mutation may impact some drug responses, but its role in artemisinin susceptibility remains unclear ${ }^{17}$. Given the adaptation of the CRISPR-Cas9 system to $P$. falciparum and new data implicating intracellular traffic in the complex artemisinin resistance phenotype, we set out to clarify the impacts of these mutations on in vitro artemisinin susceptibility and to probe the underlying biology of the AP- $2 \mu$ protein in the parasite cell.

In virtually all other eukaryotes, adaptin complexes consist of a heterotetramer and mediate endocytosis and post-Golgi inter-compartment vesicular traffic of receptor-bound cargo ${ }^{18}$. Each adaptin complex consists of four subunits: two large $(\alpha / \gamma / \delta / \varepsilon$ and $\beta)$, one medium $(\mu)$, and one small $(\sigma)^{19}$. In particular, the $\mu$ subunit interacts with cargo molecules and vesicular membranes and has important regulatory phosphorylation sites ${ }^{19,20}$. The AP-2 complex is recognised as participating in clathrin-mediated endocytosis from the plasma membrane to the early endosomal compartment in most eukaryotes ${ }^{20,21}$. To date there have been no experimental studies of adaptins in $P$. falciparum or other Apicomplexa, and AP-2 is predicted to be involved in endocytosis of haemoglobin from the host cell in P. falciparum ${ }^{16,22,23}$.

Although the mechanism of artemisinin action in the parasite remains elusive, haemoglobin metabolism is believed to activate the endoperoxide bridge in the artemisinin molecule, required for the drug's cytotoxic effect ${ }^{24-26}$. This process may thus link drug activation to trafficking of 
haemoglobin into the parasite from the host cell cytoplasm. In vitro artemisinin resistance is currently defined by survival and expansion of parasite cultures after brief drug exposure during the ring stage, mimicking artemisinin pharmacokinetics in vivo ${ }^{27}$. Reports suggest that activated artemisinin induces disseminated oxidative stress and that resistant parasites have enhanced responses to counter the impact of protein damage and redox stresses centred around the endoplasmic reticulum ${ }^{28,29}$. How resistance-associated factors, including variant K13, Coronin, or AP- $\mu$, contribute to these ringstage-specific mechanisms is still under investigation.

Here we have investigated the effect of pfap $2 m u$ mutations on artemisinin susceptibility by generating parasite lineages harbouring I592T and S160N PfAP- $2 \mu$ mutations via Cas9 genome editing. We then explore the biology of the wildtype PfAP- $2 \mu$ protein, uncovering unexpected divergences from canonical eukaryotic trafficking biology. 
bioRxiv preprint doi: https://doi.org/10.1101/621078; this version posted April 30, 2019. The copyright holder for this preprint (which was not certified by peer review) is the author/funder, who has granted bioRxiv a license to display the preprint in perpetuity. It is made available under aCC-BY-NC-ND 4.0 International license.

\section{RESULTS}

\section{A variant of AP-2 $\mu$ mediates $P$. falciparum ring-stage survival during artemisinin pressure} in vitro

Two single-nucleotide polymorphisms, encoding PcAP-2 $\mu$ (I568T), identified in P. chabaudi, and PfAP- $2 \mu(\mathrm{S} 160 \mathrm{~N})$, identified in human P. falciparum infections, have been suggested to modulate sensitivity to artemisinin in Plasmodium ${ }^{9,16}$. Using Cas9 editing, we generated clonal P. falciparum lines endogenously expressing the orthologous I592T and the naturally-occurring S160N PfAP- $2 \mu$ mutations on the chloroquine-sensitive 3D7 background (Fig. 1A-B). Transgenic parasites with the integrated mutations were obtained within three weeks of transfection and cloned (Fig. 1B).

Currently, the only validated in vitro measure of artemisinin susceptibility is the ring stage survival assay (RSA) ${ }^{27,30-32}$. Thus, we examined the survival of ring-stage parasite cultures, two clones of each mutant line, to a $4 \mathrm{~h}$ pulse of $700 \mathrm{nM}$ DHA using a modified RSA pulse protocol first described and validated by Yang et al ${ }^{32-33}$. Compared to 3D7, the two independent clones harbouring the I592T mutation displayed significantly higher $\mathrm{RSA}^{4 \mathrm{~h}}$ survival rates of $10.3 \%(\mathrm{P}=0.0011)$ and 8.0\% ( $\mathrm{P}=0.0011)$, respectively, contributing an approximately 4-5-fold increase in RSA survival when compared to wildtype progenitors. Clones harbouring the S160N mutation displayed equivalent survival after the artemisinin pulse when compared to wildtype progenitors. For comparison, Cambodian clinical isolates harbouring either the circulating R539T or C580Y K13 mutations displayed $28.0 \%$ and $17.3 \% \mathrm{RSA}^{4 \mathrm{~h}}$ survival in our hands, respectively (Fig. 1D), contributing 10.6and 6.5-fold increases in survival, respectively, compared to an isogenic $\mathrm{K} 13^{\mathrm{wt}}$ Cambodian isolate.

Standard $48 \mathrm{hr} \mathrm{EC}_{50}$ estimates for quinine, piperaquine, and mefloquine susceptibility were not affected in clones of either $p f a p 2 m u$-variant lineage, but we did observe modest, but statistically significant, potentiation (decreased $\mathrm{EC}_{50}$ ) of lumefantrine and chloroquine in both $\mathrm{I} 592 \mathrm{~T}$ clones (Fig. 1C). As previously demonstrated for other artemisinin resistant lineages, $48 \mathrm{~h} \mathrm{EC}_{50}$ estimates for artemisinin were unchanged in the I592T clones, compared to wildtype progenitors. We also generated a transgenic parasite line expressing the wildtype I592I codon in the context of silent "shield" mutations required for obliterating the Cas9 PAM site in the pfap2mu locus used during I592T editing to confirm the effects observed in the RSA and 48h assays were directly attributable to the I592T SNP. As expected, two clones of this I592I lineage demonstrate equivalent sensitivity in all assays when compared to 3D7. These data demonstrate that AP- $2 \mu$ mutation can confer significant ring-stage protection from artemisinin in an otherwise drug-susceptible P. falciparum strain in vitro.

\section{AP- $2 \mu$ is localised to a cytoplasmic compartment}

A mechanistic understanding of $1592 \mathrm{~T}$-mediated artemisinin resistance first requires knowledge of the biology of the wildtype PfAP- $2 \mu$ protein. To generate this information, we sought to characterise the cellular location, essentiality and interactome of this protein. We expected that AP- $2 \mu$ 
bioRxiv preprint doi: https://doi.org/10.1101/621078; this version posted April 30, 2019. The copyright holder for this preprint (which was not certified by peer review) is the author/funder, who has granted bioRxiv a license to display the preprint in perpetuity. It is made available under aCC-BY-NC-ND 4.0 International license.

would be involved in clathrin-mediated endocytosis from the plasma membrane based on eukaryotic trafficking dogma ${ }^{19}$. Thus, using Cas9 editing, we installed a tandem triple haemagglutinin (3xHA) epitope tag onto the C-terminus of the protein (Fig. 2A-C) and examined the localisation of AP- $2 \mu$ $3 x H A$ by IFA across the asexual lifecycle in two clones (AP- $2 \mu-3 x H A \_c 1$ and AP- $2 \mu-3 x H A \_c 2$ ). AP- $2 \mu-3 x H A$ distribution was similar in both clones, so only the data from AP- $2 \mu-3 x H A \_c 1$ are presented. Contrary to our expectations that AP- $2 \mu-3 \times$ HA would decorate the parasite plasma membrane, consistent with a role in endocytosis, we observed that, throughout the asexual cycle, AP$2 \mu$ localises to additional punctate structures in the parasite cytoplasm (Fig 2D). In the ring stage, AP$2 \mu-3 \mathrm{xHA}$ typically appears as a single focus, near the parasite plasma membrane. As the cell develops, foci increase in number and localise to a cytoplasmic compartment in trophozoites (Fig. 2D). During schizogony, the AP- $2 \mu$-labelled structure multiplies and segments into each daughter merozoite (Fig. 2D). To probe the observed punctate localisation of AP- $2 \mu$ further, its cellular distribution was examined with respect to a panel of representative organelle markers. However, the distribution of AP- $2 \mu$ signal did not correlate well with that of the ER, Golgi complex, or the apicoplast during development or with the apical secretory organelles during schizogony (Suppl. Fig. 1). When compared with brightfield, a focus of AP-2 $\mu$ was often in close apposition to the digestive vacuole, but these structures were never observed to overlap (Fig. 2D, middle column).

To better characterise the localisation of AP- $2 \mu$, we performed immunoelectron microscopy (immuno-EM) on thin sections of trophozoites expressing AP-2 $\mu-3 x$ HA. In analysis of 66 micrographs of single parasite-infected erythrocytes, gold particles detecting anti-HA antibodies bound to AP- $2 \mu-3 \times$ HA were observed at the nuclear membrane and ER (73.8\% of micrographs), in vesicles in the cytosol (37.9\%), in close proximity to tubular cytosolic structures (93.6\%), near the food vacuole (5.8\%), and, rarely, at the parasite plasma membrane (4.2\%) (Fig 2E, Suppl. Table 1). Immunostaining against the endoplasmic reticulum (ER)-resident protein disulfide isomerase (PDI) suggests that these tubular structures may be cross-sections of distal extensions of the ER (Fig. 2E). Co-staining against Rab5B, an effector of endosomal transport, suggests at least some of the cytosolic AP- $2 \mu$ associates with Rab5B ${ }^{+}$vesicles (Suppl. Fig. 2). Parasites expressing AP-2 $\mu-2 x F K B P-G F P$ showed a similar localisation by immuno-EM (Suppl. Fig. 3, Suppl. Table 1), but GFP fluorescence was too faint to reliably observe in live cells.

Because Plasmodium parasites lack a stacked Golgi apparatus, differentiating the ER and Golgi by EM is difficult. Therefore, AP- $2 \mu-3 x H A$ parasites were treated with brefeldin A (BFA), a fungal metabolite and fast-acting inhibitor of ER-to-Golgi secretory traffic. Upon stimulation with BFA, proteins localised to, or trafficked via, the Golgi relocalise to the ER. Previous studies examining intracellular traffic in Plasmodium have shown that parasite cultures can be treated with 5 $\mu \mathrm{g} / \mathrm{ml}$ BFA for up to $24 \mathrm{~h}$ while remaining viable ${ }^{34,35}$. After treating ring stage parasites with $5 \mu \mathrm{g} / \mathrm{ml}$ BFA for $16 \mathrm{~h}, \mathrm{AP}-2 \mu-3 \mathrm{xHA}$ staining significantly co-localised with staining observed for plasmepsin $\mathrm{V}$, a luminal ER protease, suggesting AP- $2 \mu$ is localised to a secretory membrane. AP- $2 \mu$ and plasmepsin V staining were distinct in solvent-treated controls. (Suppl. Fig. 4). 
bioRxiv preprint doi: https://doi.org/10.1101/621078; this version posted April 30, 2019. The copyright holder for this preprint (which was not certified by peer review) is the author/funder, who has granted bioRxiv a license to display the preprint in perpetuity. It is made available under aCC-BY-NC-ND 4.0 International license.

In recent studies, K13 has been localised to conspicuous membranous structures in the cytosol ${ }^{36}$, and these superficially resemble the structures labelled by AP- $2 \mu$ here (Fig. 2 D, E). Given the apparent similarity in cellular distribution and the importance in ring-stage artemisinin susceptibility in vitro of both molecules, we hypothesised that $\mathrm{AP}-2 \mu$ and $\mathrm{K} 13$ localise to the same cytosolic compartment. We overexpressed an episomally-encoded N-terminal GFP-K13 fusion protein in our

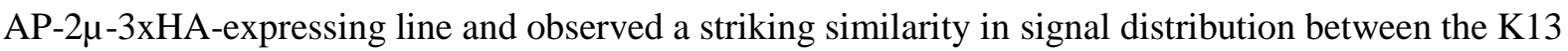
and AP- $2 \mu$ in fixed ring and schizont stages (Fig. 2 F). The GFP-K13 signal resembled what has previously been reported ${ }^{36}$.

\section{$\mathrm{PfAP}-2 \mu$ is required for asexual replication}

Given these results demonstrating an unexpected cytoplasmic localisation for AP- $2 \mu$, we sought to better characterise the protein's functional importance. Previously results suggested that AP$2 \mu$ is required for asexual replication, but its role in asexual development is unclear. Therefore, we deployed the inducible DiCre system described by Collins et al to study the phenotypic effects of conditional pfap $2 m u$ knockout (KO) in vitro ${ }^{37}$. Specifically, the Cas9 donor constructs described above were modified to install both a loxP site into the 3' UTR immediately after the pfap $2 m u$ stop codon and the loxP-containing pfsera 2 intron described by Jones et al into the 5 ' end of the gene, 261 bp into the CDS, such that Cre-mediated excision removes the majority of the coding sequence, including the 3xHA tag. These constructs were transfected into 3D7 parasites constitutively expressing dimerisable Cre recombinase ${ }^{38}$ (Fig. 3A).

Ring stage cultures of the 3D7-AP-2 $\mu$-floxed-3xHA parasites were treated with $10 \mathrm{nM}$ rapamycin (rap) in DMSO for 30 min to dimerise the split Cre recombinase and trigger pfap2mu excision. Genomic DNA was extracted 24h after this treatment, and PCR confirmed near-complete excision of the floxed region of pfap $2 m u$ (Fig. 3B), resulting in ablation of AP- $2 \mu$ protein expression (Fig. 3C). Daily parasite counts by FACS revealed that induced-KO of pfap $2 m u$ prevented parasite replication within a single asexual cycle, without appreciable recovery over multiple cycles (Fig. 3D), showing that pfap $2 m u$ is required for asexual replication in vitro. Importantly, the Cre-mediated endogenous pfap $2 m u \mathrm{KO}$ was fully complemented with an episomally-expressed copy of AP-2 $\mu$-GFP under a constitutive promoter (Fig. 3E-G; Suppl. Fig. 5). These results also support our localisation studies, indicating that disrupting AP- $2 \mu$ is lethal, and C-terminal AP- $2 \mu$ tags are thus tolerated by the parasite.

When examined by Giemsa staining, parasites lacking pfap $2 m u$ arrest as malformed schizonts (Fig. $3 \mathrm{H})$. These defective schizonts occupy approximately half of the red cell cytoplasm and contain poorly segmented merozoites compared to wild-type schizonts. Despite the reduced size of schizonts in $p f a p 2 m u$ knockouts, their DNA content is similar to that of fully segmented, egress-blocked schizonts by FACS (Suppl. Fig. 6). Rarely, rap-treated parasites were observed to undergo egress and invasion despite the addition of rapamycin and probably represent incomplete excision of pfap $2 m u$ 
across the cultured population. Supporting this, in our PCR amplification of genomic DNA extracted from these rap-treated cultures, a faint $3 \mathrm{~kb}$ band, indicative of unexcised full-length $p f a p 2 m u$, was detected (Fig. 3B). This phenomenon of incomplete Cre-mediated excision has been reported previously ${ }^{37}$.

\section{PfAP- $2 \mu$ is required for schizogony}

Examining these deformed schizonts by electron microscopy revealed that AP- $2 \mu$ deletion results in gross morphological defects during schizogony and merozoite biogenesis (Fig. 3I; Suppl. Fig. 6). Merozoites forming within AP- $2 \mu-\mathrm{KO}$ schizonts are highly disorganised and misshapen within the parental schizont plasma membrane, and there are large pockets of schizont cytosol between the malformed merozoites. The schizont plasma membrane seems indistinct, loosely encircling the deformed merozoites with irregular invaginations not seen in wild-type parasites (Fig. 3I; Suppl. Fig. 6). In AP-2 $\mu$-KO schizonts, peripheral plasma membranes were consistently poorly preserved during fixation and processing for electron microscopy despite several replicate preparations. These membrane bilayers tended to separate dramatically compared to membranes in wild-type schizonts, and we cautiously attribute this observation to increased membrane fragility in the absence of $\mathrm{AP}-2 \mu$.

Additionally, electron micrographs revealed a statistically significant accumulation of lipid bodies in the cytosol of AP-2 $\mu$ KO schizonts (Fig. 3I; Suppl. Fig. 6, black arrows), with some cells having 2, 3 or 4 such bodies (Poisson regression: coefficient $0.597,95 \%$ CI $0.344-0.850 ; \mathrm{P}<0.001 ; \mathrm{N}$ $=300$ treated, 300 untreated). These parasites were also more likely to contain disturbed digestive vacuoles (DV), which often appeared fragmented or elongated (odds ratio 3.18 (95\% CI 1.89-5.48; $\mathrm{P}<0.0001)$. Consistent with this, haemozoin crystals were occasionally observed in the schizont cytosol. Wild-type and KO trophozoites appear morphologically equivalent (Suppl. Fig. 6), and apicoplasts can be observed in these cells.

Subsequent IFA imaging supported these findings, revealing that $p f a p 2 m u$ is required for the genesis of several membrane-bound organelles (Suppl. Fig. 7). Specifically, AMA1, RON4, and CDC48, markers of the micronemes, rhoptries, and apicoplast, respectively, are mis-localised by IFA, despite being detectable at normal levels by western blot (Suppl. Fig. 7, 8). Despite the apparent mislocalisation of AMA1 and RON4 by immunofluorescence (Suppl. Fig. 7), rhoptries and micronemes are visible in some KO schizont EM sections (Fig. 3I), implying a defect in transport rather than organelle biogenesis. Additionally, in KO schizonts, MSP1 antibody staining is disrupted, suggesting that trafficking to the schizont plasma membrane, which invaginates around the nascent merozoites during schizogony, may be disrupted in the absence of AP- $2 \mu$. The parasitophorous vacuole, labelled by EXP2, seems to be largely intact though may have unusual discontinuities in some cells. The ER and cis-Golgi display no obvious abnormalities in cells lacking AP-2 $\mu$ (Suppl. Fig. 7). Overall, it is unlikely that these widespread defects are all directly attributable to AP- $2 \mu$ 
bioRxiv preprint doi: https://doi.org/10.1101/621078; this version posted April 30, 2019. The copyright holder for this preprint (which was not certified by peer review) is the author/funder, who has granted bioRxiv a license to display the preprint in perpetuity. It is made available under aCC-BY-NC-ND 4.0 International license.

function. Instead, this complex phenotype may be the result of knock-on effects of AP- $2 \mu$ deletion affecting downstream effector molecules.

\section{The AP-2 complex is clathrin-independent and associates with Kelch10}

To elucidate some of these possible AP- $2 \mu$ interacting partners, we immunoprecipitated AP$2 \mu$ and performed mass spectrometry. Trophozoite cell lysates of $P$. falciparum AP- $2 \mu-3 x H A$ were prepared using cryomilling and detergent lysis, a cell disruption technique shown to preserve labile protein-protein interactions and generate high resolution interactomes in other organisms, though not previously deployed in Plasmodium ${ }^{39}$. Using both Triton- and CHAPS-containing lysis buffers originally derived for the extraction of clathrin-interacting proteins from Trypanosoma species, we lysed frozen trophozoite pellets and performed pulldowns using anti-HA conjugated beads.

As previously discussed, AP-2 is the canonical clathrin-interacting endocytic complex in essentially all other studied eukaryotes, and we expected AP- $2 \mu$ to interact with clathrin and the other putative AP-2 subunits in P. falciparum. Four adaptor complex subunits were enriched under both lysis conditions tested, demonstrating that the AP-2 complex in P. falciparum comprises subunits annotated in the genome as AP- $2 \alpha, \mathrm{AP}-2 \sigma, \mathrm{AP}-2 \mu$ (our tagged bait protein), and AP- $1 \beta$, previously predicted to be shared between the AP-1 and AP-2 complexes ${ }^{40}$ (Fig. 4A - C). This latter subunit is therefore designated here as AP-1/2 $\beta$. Putative nucleotide-dependent regulators of vesicular traffic and a kelch-type propeller domain protein encoded on chromosome 10, K10, were also identified with high confidence under one or both lysis conditions (Fig. 4C; Suppl. Table 3). Though the K10 propeller domain shares little sequence identity with that of K13, pfk10 has previously been identified as a locus of interest in a genetic study of artemisinin resistance ${ }^{41}$. K13 was not identified as an AP$2 \mu$-interacting protein in our immunoprecipitation data. Additionally, a putative EH-domain containing protein with homology to EPS15 (a classical AP-2 interacting partner) was enriched in the immunoprecipitation. Strikingly, neither the clathrin heavy chain (CHC) (gene ID: PF3D7_1219100) nor the light chain (CLC) (gene ID: PF3D7_1435500) were enriched in either extraction condition with our HA-tagged AP- $2 \mu$, contrary to expectation.

To validate our interactome, we confirmed that AP- $2 \mu-3 \times$ HA copurifies with episomallyexpressed and immunoprecipitated K10-GFP but not similarly expressed cytosolic GFP (Fig. 4D). We sought to confirm the absence of interacting clathrin by direct IP of CHC from P. falciparum AP- $2 \mu-$ $3 x H A$ lysates and western blotting with anti-HA antibodies. We were still unable to find evidence that AP-2 $\mu$-3xHA co-purifies with immunoprecipitated CHC (Fig. 5D). Using the same clathrin antibody, first validated on a parasite line expressing PfCHC-2xFKBP-GFP (Fig. 5A), we also found that AP$2 \mu-3 \times \mathrm{xHA}$ and $\mathrm{CHC}$ are localised to separate compartments by IFA (Fig. 5E).

To test robustly the observation that AP-2 does not interact with $\mathrm{CHC}$, we performed a similar IP-MS analysis on a trophozoite preparation of parasites expressing CHC-2xFKBP-GFP. As expected ${ }^{42}$, all AP-1 complex components were enriched in these PfCHC pulldowns, including AP- 
bioRxiv preprint doi: https://doi.org/10.1101/621078; this version posted April 30, 2019. The copyright holder for this preprint (which was not certified by peer review) is the author/funder, who has granted bioRxiv a license to display the preprint in perpetuity. It is made available under aCC-BY-NC-ND 4.0 International license.

$1 / 2 \beta$, as were other trafficking-associated components (Fig. 5B; Suppl. Table 4). However, no peptides from AP-2 $\alpha, \mu$, and $\sigma$ subunits were identified in MS analysis of four replicate pulldowns (Fig. 5B, 5C). AP-2 independent clathrin-dependent endocytosis has been demonstrated in African trypanosomes, where the genes encoding the AP-2 subunits are absent, and also suggested in T. cruzi where clathrin does not appear to interact with AP-2, but has never before been demonstrated in Plasmodium. AP-3 complex subunits were also identified but were not enriched compared to controls. The role of the AP-4 complex is unclear in eukaryotes, but this complex is not believed to interact with clathrin. Consistent with this, we did not detect peptides corresponding to the P. falciparum AP4 complex. Interestingly, we found peptides corresponding to Sortilin, Vps9, a DnaJ chaperone, and RESA enriched in the clathrin interactome, among other exported and trafficking-related factors. Collectively these data suggest that retromer, trans-Golgi, and secretory trafficking likely involve clathrin-coated vesicles (Suppl. Table 4). Consistent with these diverse active processes, our localisation of PfCHC demonstrates many rapidly-cycling foci decorating the plasma membrane and cytoplasmic structures in live trophozoites (Fig. 5F). This dynamic localisation was never observed for AP-2 in our imaging studies. These data support a novel, clathrin-independent role for the AP-2 complex in Plasmodium.

\section{Disruption of trafficking confers high-level artemisinin resistance in vitro}

As a first step to explore the mechanism of the AP- $2 \mu(\mathrm{I} 592 \mathrm{~T})$-mediated artemisinin resistance phenotype reported above, we lastly proposed that disruption of intracellular traffic would increase parasite tolerance to artemisinin exposure. In higher-order eukaryotes, blockade of secretory traffic instigates an eIF2 $\alpha$-dependent cell stress response ${ }^{44}$, a process recently shown to underlie K13mediated artemisinin resistance in P. falciparum ${ }^{45}$. Interestingly, as transient BFA exposure rapidly and reversibly inhibits secretory traffic from the ER, an impact also seen with transient incubations of parasites at $15-20^{\circ} \mathrm{C}^{46}$, a recent study by our laboratory showed that transient incubations at these temperatures dramatically increased parasite survival to artemisinin during an $\mathrm{RSA}^{4 \mathrm{~h}}$ pulse ${ }^{33}$. Thus, to provide further evidence that intact secretory traffic in early ring-stage parasites is important for artemisinin susceptibility, we treated highly synchronised ring stage parasites with BFA for 1 hour from hours 2-3 post-invasion ${ }^{34}$. At hour 3, we initiated the RSA ${ }^{4 h}$ as described in the presence of this BFA, and at hour 7 we washed both compounds off extensively, returning the treated cells to culture. We compared $\mathrm{BFA}^{\text {5h }}$-treated 3D7 parasite survival in the RSA ${ }^{4 \mathrm{~h}}$ to that of untreated cells (Fig. 6A). In the absence of DHA, the BFA ${ }^{5 h}$ treatment had little effect on parasite proliferation (Fig. 6B), as previously reported, but this treatment markedly increased eIF2 $\alpha-\mathrm{P}$, the cell stress indicator previously detected in artemisinin-resistant $\mathrm{K} 13^{\text {mut }}$ parasites (Fig. 6C). In the RSA ${ }^{4 h}$, the presence of BFA provided substantial protection, with $45 \%$ of $\mathrm{BFA}^{5 \mathrm{~h}}$-treated parasites surviving the DHA exposure, compared with less than $3 \%$ of solvent-treated control (Fig. 6C). It is notable that we also detected low levels of eIF2 $\alpha-\mathrm{P}$ in solvent-treated ring stage parasites, in contrast to previous reports 
bioRxiv preprint doi: https://doi.org/10.1101/621078; this version posted April 30, 2019. The copyright holder for this preprint (which was not certified by peer review) is the author/funder, who has granted bioRxiv a license to display the preprint in perpetuity. It is made available under aCC-BY-NC-ND 4.0 International license.

45. These data show that transient chemical blockade of secretory traffic is sufficient to generate a K13-like artemisinin resistance phenotype, adding to the evidence that both intracellular traffic and the cell stress response may be important determinants of ring-stage parasite susceptibility to artemisinin in vitro.

\section{Discussion}

In this study, we implicate the $\mu$ subunit of the P. falciparum AP-2 adaptor complex in artemisinin susceptibility in vitro and provide functional insights into the role of this complex in Plasmodium, highlighting several divergences from eukaryotic dogma. Specifically, we introduced a mutation, first identified in artemisinin-resistant $P$. chabaudi, into the orthologous $P$. falciparum locus by genome editing. This demonstrated an enhanced ring-stage artemisinin survival phenotype similar to, though less severe than, the genetically-distinct K13-mediated phenotypes reported in Southeast Asian strains. Interestingly, a mutation in the $\alpha$-subunit of the same AP-2 complex was recently identified in an experimentally evolved artemisinin-resistant $P$. falciparum clone ${ }^{47}$, providing further support for our conclusion that the AP-2 complex is capable of, and central to, modulating parasite susceptibility to artemisinin. Further, Demas et al. ${ }^{14}$ have recently demonstrated K13-independent ring-stage resistance in vitro mediated by variants of the $P$. falciparum Coronin protein. Coronin has been proposed to interact with EPS15, an AP-2 partner described in other eukaryotes, a homologue of which was identified here as interacting with AP- $2 \mu$ in P. falciparum (Fig. 4C; Suppl. Table 3). We also clarify that the PfAP- $2 \mu(\mathrm{S} 160 \mathrm{~N})$ mutation currently circulating in African parasite populations does not impact ring-stage artemisinin sensitivity in the 3D7 genetic background.

By interrogating the localisation of epitope-tagged AP- $2 \mu$ using immunofluorescence and immunoelectron microscopy, we provide evidence that the AP-2 complex is localised to the plasma membrane as well as distinct cytoplasmic foci, likely corresponding to vesicles throughout the cytosol during intra-erythrocytic development. These foci segregate into merozoites during schizogony before being carried into the nascent parasite. By immunoelectron microscopy, we show that these vesicles partially co-label with ER-resident PDI, as well as with Rab5B, a protein associated with the parasite plasma membrane and digestive vacuole as trafficking destinations. Surprisingly, these vesicles also correspond well with K13-labelled structures within the resolution limits of light microscopy, though we find no evidence of direct interaction between the two molecules. Instead, AP- $2 \mu$ associates with another kelch-type protein, $P$. falciparum K10, and also with potential trafficking chaperones and regulators.

We demonstrate that the AP- 2 complex contains $\alpha 2, \mu 2$ and $\sigma 2$ subunits plus a $\beta$-subunit that supplies both the AP-1 and AP-2 complexes. This promiscuous behaviour has been reported previously in other organisms, where it has functional importance for targeting the vesicular complex to specific membranes ${ }^{48}$. Further work is required to determine if this is also true of $\beta 1 / 2$ in Plasmodium. Additionally, we provide the first description of $\mathrm{CHC}$ in P. falciparum and find no evidence of interaction or co-localisation with AP-2, despite identifying other adaptor complex 
bioRxiv preprint doi: https://doi.org/10.1101/621078; this version posted April 30, 2019. The copyright holder for this preprint (which was not certified by peer review) is the author/funder, who has granted bioRxiv a license to display the preprint in perpetuity. It is made available under aCC-BY-NC-ND 4.0 International license.

subunits in a CHC pulldown. This was surprising because AP-2 is the canonical clathrin adaptin complex of eukaryotes, although a similar result was obtained for AP-2 in $T$. cruzi ${ }^{43}$. A previous study of AP- $1 \mu$ in P. falciparum identified $\mathrm{CHC}$ as an interacting partner ${ }^{46}$, and we recapitulate this, showing that all four components of the AP-1 complex immunoprecipitate with $\mathrm{CHC}$. This suggests that despite the shared $\beta$ subunit, which canonically links the AP complex to clathrin, other subunits or factors may be involved in coat protein selection in Plasmodium falciparum. The coat protein (or proteins) associated with PfAP-2 vesicles remains unknown but may lie among the many proteins of unknown function identified in our AP-2 interactome (Fig. 4; Suppl. Table 2). Future studies should aim to further define AP-2- and clathrin-mediated traffic in Apicomplexans and establish whether other adaptins perform similarly diverged non-canonical roles, potentially with impacts on drug susceptibility, immune evasion and the basic biology of the parsite cell. It remains to be determined if such AP-2-independent clathrin-trafficking is more widespread, as the presence of such a pathway in two evolutionarily distinct protsists suggests this may be a more general phenomenon.

Further to these unexpected findings, we show conditional AP- $2 \mu$ deletion causes profound defects in membrane segregation and organellar integrity during schizont maturation, and prevents intra-erythrocytic growth of $P$. falciparum in vitro. It is difficult to tease out which aspects of the complex observed phenotype are secondary to AP- $2 \mu$ knockout and which are primary. Colocalisation of $\mu 2$ and Rab5B by immunoelectron microscopy may suggest that the observed plasma membrane fragility, lipid droplet accumulation, and disrupted digestive vacuoles are interrelated. AP$2 \mu \mathrm{KO}$ may disrupt retromer-like trafficking needed to recycle lipid from the digestive vacuole back to the plasma membrane, leading to lipid accumulation near the digestive vacuole and insufficient fatty acids available for growing and segregating membranes during schizogony. This potential role for AP-2 in membrane organisation in schizonts may impact the integrity of apical secretory organelles, as several key factors are mislocalised in nascent merozoites upon AP- $2 \mu$ KO (Suppl. Fig. $7,8)$. These observations and the specific directionality of AP-2 traffic require further investigation.

Our data, although supportive of a link between trafficking, K13, and artemisinin susceptibility, can provide no new direct insights into the elusive function of K13 in P. falciparum. Previous studies have suggested K13 may be a ubiquitin ligase scaffolding factor and associated with PI3P-labeled secretory vesicles in the cell ${ }^{49,50}$. A general role for K13 in intracellular traffic determined by these studies fits well with our data, but further work is necessary to reconcile those studies with others showing a conflicting role for PI3P ${ }^{51}$ and implicating autophagy in modulating artemisinin susceptibility ${ }^{52}$. As a recycling process, autophagy is dependent upon intracellular trafficking, and we demonstrate that AP-2 deletion clearly affects similar processes.

Interference with intracellular traffic, in our hands via either transient BFA treatment in this study or temperature modulation ${ }^{33,46}$, induces a profound artemisinin resistance phenotype in genetically wildtype 3D7 parasites. As we show, BFA induces regulatory phosphorylation of eIF2 $\alpha$, a hallmark of the cell stress response and globally attenuated protein synthesis, which mechanistically underlies artemisinin resistance. Consistent with this, previous data indicate that similar transient BFA 
treatments also stall development and translation in Plasmodium ring stages ${ }^{34}$. We interpret these data to indicate that the fidelity of intracellular trafficking is intimately linked with this stress response, and we anticipate that AP-2 mutation mechanistically disrupts the processes observed here. Further studies characterising our AP- $2 \mu($ I592T) mutant, in particular those examining membrane organisation, DV integrity, and stress response activation, are planned.

Resistance to artemisinin has long been thought to be multigenic, consistent with our model presented above ${ }^{14,53}$. So far, laboratory evolution of artemisinin resistance has mostly generated parasites with $\mathrm{K} 13$ mutations that are different from those most prevalent in the field, or mutations in other loci altogether, such as the recently-described pfcoronin ${ }^{6,14,47}$. Similarly, the AP- $2 \mu($ I592T) mutation described in this study has not been observed in human infections. However, using the descriptive characterisation provided here of the wildtype PfAP- $2 \mu$ molecule as a platform, full characterisation of the I592T variant can now proceed, with the aim of understanding the mechanism by which in vitro artemisinin susceptibility is significantly reduced. 
bioRxiv preprint doi: https://doi.org/10.1101/621078; this version posted April 30,2019. The copyright holder for this preprint (which was not certified by peer review) is the author/funder, who has granted bioRxiv a license to display the preprint in perpetuity. It is made available under aCC-BY-NC-ND 4.0 International license.

\section{Materials and Methods}

\section{Plasmid Design and Construction.}

Two plasmids were created for transfecting 3D7 parasites: pL6-AP2 $\mu($ I592T)-sgDNA and pL6AP2 $\mu$ (I592I)-sgDNA. These constructs utilized the plasmid system described by Ghorbal et al. and encoded the donor sequence carrying the mutation of interest and the guide $\mathrm{RNA}^{54}$. The pfap2mu_I592T donor template was created by first amplifying the 5' homology region with primers $\mathrm{P} 1$ and $\mathrm{P} 2$ and the 3' homology region with primers $\mathrm{P} 3$ and P4. These two fragments were assembled by overlap PCR using primers P1 and P4; the resulting fragment was cloned into pL6-eGFP with EcoRI and NcoI. Primers P5 and P6 were annealed to create a dsDNA molecule encoding the sgRNA sequence with 5' and 3' extensions to enable InFusion Cloning (Clontech) into BtgZI-digested pL6. To create the AP2 $\mu$ (I592I) donor fragment, primers P2 and P3 mentioned above were replaced with P7 and P8. Primer sequences are provided in Supplementary Table 22.

\section{Parasite Culture and Generation of Transgenic Parasites}

Plasmodium falciparum culture was performed in $\mathrm{AB}+$ red blood cells obtained from the UK National Blood \& Tissue Service, in RPMI supplemented with Albumax II, L-glutamine, and gentamycin, at $5 \%$ haematocrit under $5 \% \mathrm{CO}_{2}$ conditions at $37^{\circ} \mathrm{C}$, and synchronised using $70 \%$ Percoll gradients to capture schizonts or $5 \%$ sorbitol to isolate ring-stage parasites.

To establish the techniques in our laboratory, two transfection methods were used in this study. For integration of SNPs, ring stage transfection was performed. Briefly, 3D7 parasites were cultured to approximately $10-15 \%$ parasitaemia in 5\% haematocrit under standard conditions. Immediately before transfection, $100 \mu \mathrm{g}$ of each plasmid (pL6 and pUF1-Cas9) was ethanol-acetate precipitated and resuspended in $100 \mu 1$ of sterile TE. $300 \mu 1$ of infected red cells were isolated by centrifugation and equilibrated in 1 x Cytomix $(120 \mathrm{mM} \mathrm{KCl}, 5 \mathrm{mM} \mathrm{MgCl} 2,25 \mathrm{mM}$ HEPES, 0.15

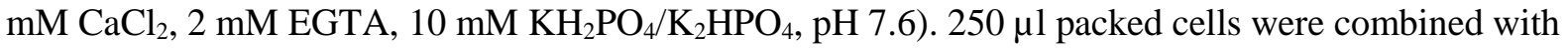
$250 \mu \mathrm{l}$ of $1 \mathrm{x}$ Cytomix in a $2 \mathrm{~mm}$ transfection cuvette (Bio-Rad Laboratories). The precipitated and resuspended DNA was added to the cell suspension in the cuvette. The cells were immediately pulsed at $310 \mathrm{~V}, 950 \mu \mathrm{F}$, and infinite resistance in a Bio-Rad Gene Pulser. The electroporated cells were then washed twice in complete media to remove debris and returned to culture. Fresh red blood cells were added to approximately $5 \%$ total haematocrit on day 1 after transfection along with $2.5 \mathrm{nM}$ WR99210 and $1.5 \mu \mathrm{M}$ DSM-1. Media and selection drugs were replenished every day for 14 days and then every 3 days until parasites were observed by microscopy. Parasites recovered approximately 3 weeks post-transfection. The tagged $\mu 2$ parasite line was created by the spontaneous DNA uptake method exactly as described by Deitsch et $a l^{55}$. The 3D7- $\mu 2-2 x F K B P-G F P$ and 3D7-CHC-2xFKBP-GFP parasite lines were generously provided by Tobias Spielmann and generated via selection-linked integration ${ }^{36}$. The 3D7 DiCre-expressing parasite line ${ }^{37}$ and Cam3.II family parasite lines ${ }^{13}$ were generously provided by Michael Blackman and David Fidock, respectively. 
bioRxiv preprint doi: https://doi.org/10.1101/621078; this version posted April 30,2019. The copyright holder for this preprint (which was not certified by peer review) is the author/funder, who has granted bioRxiv a license to display the preprint in perpetuity. It is made available under aCC-BY-NC-ND 4.0 International license.

\section{Drug Susceptibility Assays.}

Synchronised ring stage parasites at $0.5 \%$ parasitaemia and $2 \%$ haematocrit were exposed to a range of dihydroartemisinin, quinine, chloroquine, lumefantrine, piperaquine, and mefloquine concentrations over a full lifecycle in two biological replicates within 96-well microtitre plates, following standard procedures in our laboratory. Serial two-fold drug dilutions were performed across the plate using complete media; parasites were added thereafter. The plate was incubated at $37^{\circ} \mathrm{C}$ for 48 hours, freeze-thawed, and drug sensitivity quantitated using SYBR Green fluorescence as described ${ }^{56}$. Parasite survival was normalised between parasites exposed to $10 \mu \mathrm{M}$ chloroquine and a drug-free control. $\mathrm{EC}_{50}$ estimates were determined using a non-linear regression fit in GraphPad Prism (GraphPad Software, San Diego California USA, version 7.01).

DHA drug-pulse experiments were carried out using our previously published RSA ${ }^{0-4 h}$ format, ${ }^{44}$ itself a modification of the RSA ${ }^{0-6 \mathrm{~h}}$ of Witkowski et al. ${ }^{27}$ and the RSA ${ }^{0-3 \mathrm{~h}}$ approach of Yang et al. ${ }^{32}$. Survival estimates were based on FACS counts performed on live cells using 1:10,000 MitoTracker Deep Red and 1:1,000 SYBR Green (Invitrogen Molecular Probes) stain in PBS. Cells were stained using 8 volumes of stain solution per volume of culture (2\% HCT) and analysed on a LSR-II Flow Cytometer (BD Biosciences). Statistical significance was determined by the two-sample Wilcoxon rank-sum (Mann-Whitney) test.

\section{Fluorescence Microscopy.}

To prepare slides for immunofluorescence microscopy, thin smears were first prepared on glass slides and quickly dried. Sections for staining were marked with a hydrophobic pen. Cells were fixed for 10 minutes with $4 \%$ formaldehyde in PBS, washed three times with PBS, permeabilised with $0.1 \%(\mathrm{v} / \mathrm{v})$ Triton X-100 in PBS for 10 minutes, washed again, and blocked for 1 hour with 3\% (w/v) BSA in PBS. Primary antibodies were diluted in PBS containing 3\% (w/v) BSA and $0.1 \%(\mathrm{v} / \mathrm{v})$ Tween20 and incubated on the slide overnight at $4^{\circ} \mathrm{C}$. Slides were again washed several times with PBS and incubated with secondary antibodies diluted in the same buffer. Slides were incubated for 1 hour at room temperature and washed. Glass coverslips were mounted with $1 \mu \mathrm{l}$ of Vectashield with DAPI. Images were taken on a Nikon TE-100 inverted microscope.

\section{Electron Microscopy.}

For ultrastructural analysis, $P$. falciparum were cultured at $37^{\circ} \mathrm{C}$ in $4 \mathrm{~mL}$ volumes in 6-well tissue culture dishes (Techno Plastic Products) at 2\% hematocrit until reaching 6-10\% parasitemia. Cultures were synchronized until $>80 \%$ of parasites were in ring stage growth and then treated for $1 \mathrm{~h}$ with 10 $\mathrm{nM}$ rapamycin to excise $p f a p 2 \mu$. Cultures treated with DMSO were used as negative controls. Parasites were then washed twice with RPMI and incubated at $37^{\circ} \mathrm{C}$ until harvesting. Synchronised parasites were magnetically sorted in both the trophozoite and the schizont stages by passage through a magnetically mounted MACS LD separation column (Miltenyi Biotech, Germany), collected by centrifugation and fixed in 2\% paraformaldehyde/2.5\% glutaraldehyde (Polysciences Inc., 
bioRxiv preprint doi: https://doi.org/10.1101/621078; this version posted April 30,2019 . The copyright holder for this preprint (which was not certified by peer review) is the author/funder, who has granted bioRxiv a license to display the preprint in perpetuity. It is made available under aCC-BY-NC-ND 4.0 International license.

Warrington, PA) in $100 \mathrm{mM}$ cacodylate buffer, $\mathrm{pH} 7.2$ for $1 \mathrm{~h}$ at room temperature. Samples were washed in cacodylate buffer and post-fixed in 1\% osmium tetroxide (Polysciences Inc.) for $1 \mathrm{~h}$. Samples were then rinsed extensively in $\mathrm{dH}_{2} \mathrm{O}$ prior to en bloc staining with $1 \%$ aqueous uranyl acetate (Ted Pella Inc., Redding, CA) for $1 \mathrm{~h}$. Following several rinses in $\mathrm{dH}_{2} \mathrm{O}$, samples were dehydrated in a graded series of ethanol and embedded in Eponate 12 resin (Ted Pella Inc.). Sections of $90 \mathrm{~nm}$ were cut with a Leica Ultracut UCT ultramicrotome (Leica Microsystems Inc., Bannockburn, IL), stained with uranyl acetate and lead citrate, and viewed on a JEOL 1200 EX transmission electron microscope (JEOL USA Inc., Peabody, MA) equipped with an AMT 8 megapixel digital camera (Advanced Microscopy Techniques, Woburn, MA).

\section{Immunoelectron Microscopy.}

Parasites at 2\% hematocrit and 6-8\% parasitemia were magnetically sorted from uninfected RBCs and ring stage parasites via MACS LD separation columns (Miltenyi Biotech, Germany), collected by centrifugation and fixed for $1 \mathrm{~h}$ at $4^{\circ} \mathrm{C}$ in $4 \%$ paraformaldehyde (Polysciences Inc., Warrington, PA) in $100 \mathrm{mM}$ PIPES/0.5 mM MgCl $2, \mathrm{pH}$ 7.2. Samples were then embedded in $10 \%$ gelatin, infiltrated overnight with $2.3 \mathrm{M}$ sucrose $/ 20 \%$ polyvinyl pyrrolidone in PIPES/ $/ \mathrm{MgCl}_{2}$ at $4^{\circ} \mathrm{C}$ and finally trimmed, frozen in liquid nitrogen, and sectioned with a Leica Ultracut UCT7 cryo-ultramicrotome (Leica Microsystems Inc., Bannockburn, IL). $50 \mathrm{~nm}$ sections were blocked with 5\% fetal bovine serum (FBS)/5\% normal goat serum (NGS) for $30 \mathrm{~min}$ and subsequently incubated with primary antibody for $1 \mathrm{~h}$ at room temperature (anti-PDI mouse 1:100 (1D3; Enzo Life Sciences), anti-GFP rabbit 1:200 (A-11122; Life Technologies), anti-GFP mouse 1:100 (11814460001; Roche), anti-HA rabbit 1:50 (H6908; Sigma-Aldrich), anti-Rab5a rabbit 1:50 (Gordon Langsley) and anti-Rab5b rat 1:50 (Gordon Langsley). Secondary antibodies were added at 1:30 for $1 \mathrm{~h}$ at RT (12 $\mathrm{nm}$ Colloidal Gold AffiniPure Goat anti-Rabbit IgG (H+L)(111-205-144), 18 nm Colloidal Gold AffiniPure Goat anti-Rabbit IgG $(\mathrm{H}+\mathrm{L})(111-215-144), 12 \mathrm{~nm}$ Colloidal Gold AffiniPure Goat anti-Mouse IgG (H+L)(115-205-146), and $18 \mathrm{~nm}$ Colloidal Gold AffiniPure Goat anti-Mouse IgG+IgM (H+L)(115-215-068) (Jackson ImmunoResearch). Sections were then stained with $0.3 \%$ uranyl acetate $/ 2 \%$ methyl cellulose, and viewed on a JEOL 1200 EX transmission electron microscope (JEOL USA Inc., Peabody, MA) equipped with an AMT 8 megapixel digital camera and AMT Image Capture Engine V602 software (Advanced Microscopy Techniques, Woburn, MA). All labeling experiments were conducted in parallel with controls omitting the primary antibody. These controls were consistently negative at the concentration of colloidal gold conjugated secondary antibodies used in these studies.

\section{Antibodies.}

Anti-HA (Roche, 3F10 clone) was obtained commercially. Anti-Clathrin Heavy Chain (rabbit) antibodies were generously donated by Frances Brodsky. We thank Gordon Langsley for making antiRab5B antibodies available. Anti-eIF2a antibodies were generously gifted by William Sullivan. 
bioRxiv preprint doi: https://doi.org/10.1101/621078; this version posted April 30,2019. The copyright holder for this preprint (which was not certified by peer review) is the author/funder, who has granted bioRxiv a license to display the preprint in perpetuity. It is made available under aCC-BY-NC-ND 4.0 International license.

\section{Pulldown and Mass Spectrometry.}

For cryomilling, lysate preparation, and immunoprecipitation, $P$. falciparum cultures were grown to approximately $8 \%$ parasitaemia in $5 \%$ haematocrit in approximately $6 \mathrm{~L}$ of complete medium, harvested by centrifugation at trophozoite stage and lysed with $0.15 \%(\mathrm{w} / \mathrm{v})$ saponin in PBS at $4^{\circ} \mathrm{C}$. Parasites were harvested by centrifugation at $13 \mathrm{~K}$ RPM for 5 minutes at $4^{\circ} \mathrm{C}$ and washed several times with cold PBS to remove haemoglobin and red cell debris. The washed, packed parasites were resuspended to $50 \%$ density in $\mathrm{PBS}$, flash frozen in liquid nitrogen, and stored at $-80^{\circ} \mathrm{C}$. This process was repeated until 6-8 $\mathrm{ml}$ of resuspended parasites had been stored. The frozen material was placed directly into the ball chamber of a liquid $\mathrm{N}_{2}$-cooled cryomill (Retsch) and milled under 7 cycles of 3 minutes cooling and 3 minutes milling. The milled powder was then carefully removed from the ball chamber and stored in liquid $\mathrm{N}_{2}$. All steps were performed at or below $-80^{\circ} \mathrm{C}$ to prevent parasite material from thawing. $300 \mathrm{mg}$ of the milled powder per replicate was lysed in buffer A ( $20 \mathrm{mM}$ HEPES, $100 \mathrm{mM} \mathrm{NaCl}, 0.1 \%$ (v/v) Triton X-100, $0.1 \mathrm{mM}$ TLCK, protease inhibitors (Complete Protease Inhibitor Cocktail tablet, EDTA-free, Roche), pH 7.4) or buffer B (20 mM HEPES, 250 mM sodium citrate, $0.1 \%$ (w/v) CHAPS, $1 \mathrm{mM} \mathrm{MgCl} 2,10 \mathrm{mM} \mathrm{CaCl}_{2}, 0.1 \mathrm{mM}$ TLCK, protease inhibitors, $\mathrm{pH}$ 7.4). Buffer B was previously optimised to immunoprecipitate clathrin heavy chain from T. brucei ${ }^{43}$. The lysate was sonicated and clarified by centrifugation. For 3D7-AP- $2 \mu-3 x H A$ the soluble extract was incubated with $240 \mu \mathrm{l}$ anti-HA magnetic beads (Pierce, ThermoFisher) for 1 hour. Beads were washed three times with lysis buffer several times, and bound material was eluted by suspending the beads in $80 \mu \mathrm{l}$ non-reducing LDS buffer (Invitrogen) and incubating at $70^{\circ} \mathrm{C}$ for 10 minutes. After removing the beads NuPAGE sample-reducing agent (ThermoFisher) was added to the supernatant.

The PfCHC-2xFKBP-GFP soluble extract in buffer B was incubated with $4 \mu 1$ recombinant anti-GFP nanobodies covalently coupled to surface-activated Epoxy magnetic beads (Dynabeads M270 Epoxy, ThermoFisher) for 1 hour. Beads were washed three times in buffer B and finally eluted in $80 \mu \mathrm{LDS}$ buffer (Invitrogen), supplemented with NuPAGE, at 70 ${ }^{\circ} \mathrm{C}$ for 10 minutes. The eluates were concentrated in a speed-vac to $30 \mu \mathrm{l}$ and run approximately 1.2 $\mathrm{cm}$ into an SDS-PAGE gel. The respective gel region was sliced out and subjected to tryptic digest, reductive alkylation. Eluted peptides were analysed by liquid chromatography tandem mass spectrometry (LC-MS/MS) on a Dionex UltiMate 3000 RSLCnano System (Thermo Scientific, Waltham, MA, USA) coupled to an Orbitrap Q Exactive mass spectrometer (Thermo Scientific) at the University of Dundee Finger- Prints Proteomics facility. Mass spectra were processed using MaxQuant version 1.5, using the intensity-based label-free quantification (LFQ) method ${ }^{57,58}$. Minimum peptide length was set at six amino acids and false discovery rates (FDR) of 0.01 were calculated at the levels of peptides, proteins and modification sites based on the number of hits against the reversed sequence database. Ratios were calculated from label-free quantification intensities using only peptides that could be uniquely mapped to a given protein. The software Perseus was used for statistical analysis of the LFQ data ${ }^{59}$. 
bioRxiv preprint doi: https://doi.org/10.1101/621078; this version posted April 30,2019 . The copyright holder for this preprint (which was not certified by peer review) is the author/funder, who has granted bioRxiv a license to display the preprint in perpetuity. It is made available under aCC-BY-NC-ND 4.0 International license.

\section{Disruption of Secretory Traffic with Brefeldin A.}

Synchronous wild-type 3D7 cultures were treated with $5 \mu \mathrm{g} / \mathrm{ml}$ BFA or solvent only from hour 2 postinvasion, and a subsequent $\mathrm{RSA}^{4 \mathrm{~h}}$ with $700 \mathrm{nM}$ DHA performed from hours 3 to 7 , after which both drug and BFA were washed off, and the parasites returned to drug-free culture to a total of 72 hours post-invasion.

\section{Author Contributions}

$\mathrm{RCH}$ conceived, designed, and executed the study. $\mathrm{RCH}$ performed cell culture, transfections, cryomilling and pulldowns, MS sample preparation, fluorescence microscopy, and drug susceptibility assays. RLE and AOJ designed and performed electron microscopy experiments. MZ performed cryomilling, pulldowns, and mass spectrometry analysis, supported by MCF. DVS performed cell culture and drug susceptibility assays. FM performed cell culture and assisted the design and execution of the study. MH and RM assisted the design and execution of the study. SDN performed cell culture and assisted the design and execution of the study. AP and CF supported the design and execution of the study. DB assisted with study design and supported the study. CJS conceived, designed and supported the study, and performed statistical analyses. RCH and CJS wrote the manuscript, with input from all other authors.

\section{Acknowledgements}

We would like to extend our gratitude to members of the Departments of Infection and Immunity and Pathogen Molecular Biology at LSHTM for their mentorship and helpful conversations. We thank Wandy Beatty of the Washington University Molecular Microbiology Imaging Facility for helpful assistance. We thank Douglas Lamond and the Fingerprints Proteomics facility at the University of Dundee for invaluable support. RCH was supported by the UK Foreign and Commonwealth Office through the Marshall Scholarship Programme; CJS is supported by Public Health England; MZ and MCF are supported by Wellcome Trust 204697/Z/16/Z (to MCF). MCF is a Wellcome Trust Investigator. AOJ is supported by National Institutes of Health R01 AI103280 and R01 AI123433, and is a Burroughs Wellcome Fund Investigator in the Pathogenesis of Infectious Diseases (PATH). RWM and FM are supported by an MRC Career Development Award (MR/M021157/1) jointly funded by the UK Medical Research Council and Department for International Development. MNH is supported by a Bloomsbury Colleges research studentship. The Pf-Rab5b antibody was kindly provided by Gordon Langsley (Institut Cochin, France).

\section{Competing Financial Interests}

The authors declare no competing financial interests. 
bioRxiv preprint doi: https://doi.org/10.1101/621078; this version posted April 30, 2019. The copyright holder for this preprint (which was not certified by peer review) is the author/funder, who has granted bioRxiv a license to display the preprint in perpetuity. It is made available under aCC-BY-NC-ND 4.0 International license.

\section{References}

1. World Health Organization (2017) World Malaria Report. World Health Organization doi:101071/EC12504.

2. Dondorp AM, Nosten F, Yi P, Das D, Phyo AP, Tarning J, Lwin KM, Ariey F, Hanpithakpong W, Lee SJ, Ringwald P, Silamut K, Imwong M, Chotivanich K, Lim P, Herdman T, An SS, Yeung S, Singhasivanon P, Day NP, Lindegardh N, Socheat D, White NJ (2009) Artemisinin resistance in Plasmodium falciparum malaria. $N$ Engl J Med 361: 455-467.

3. Saunders D L, Vanachayangkul, P, Lon, C (2014) Dihydroartemisinin-piperaquine failure in Cambodia. N Engl J Med 371: 484-485.

4. Thanh NV, Thuy-Nhien N, Tuyen NT, Tong NT, Nha-Ca NT, Dong LT, Quang HH, Farrar J, Thwaites G, White NJ, Wolbers M, Hien TT (2017) Rapid decline in the susceptibility of Plasmodium falciparum to dihydroartemisinin-piperaquine in the south of Vietnam. Malar J 16: 27.

5. Imwong M, Hien TT, Thuy-Nhien NT, Dondorp AM, White NJ (2017) Spread of a single multidrug resistant malaria parasite lineage (PfPailin) to Vietnam. Lancet Infect Dis 17: 10221023.

6. Ariey F, Witkowski B, Amaratunga C, Beghain J, Langlois AC, Khim N, Kim S, Duru V, Bouchier C, Ma L, Lim P, Leang R, Duong S, Sreng S, Suon S, Chuor CM, Bout DM, Ménard S, Rogers WO, Genton B, Fandeur T, Miotto O, Ringwald P, Le Bras J, Berry A, Barale JC, Fairhurst RM, Benoit-Vical F, Mercereau-Puijalon O, Ménard D. (2013) A molecular marker of artemisininresistant Plasmodium falciparum malaria. Nature 505: 50-55.

7. Ashley EA, Dhorda M, Fairhurst RM, Amaratunga C, Lim P, Suon S, Sreng S, Anderson JM, Mao S, Sam B, Sopha C, Chuor CM, Nguon C, Sovannaroth S, Pukrittayakamee S, Jittamala P, Chotivanich K, Chutasmit K, Suchatsoonthorn C, Runcharoen R, Hien TT, Thuy-Nhien NT, Thanh NV, Phu NH, Htut Y, Han KT, Aye KH, Mokuolu OA, Olaosebikan RR, Folaranmi OO, Mayxay M, Khanthavong M, Hongvanthong B, Newton PN, Onyamboko MA, Fanello CI, Tshefu AK, Mishra N, Valecha N, Phyo AP, Nosten F, Yi P, Tripura R, Borrmann S, Bashraheil M, Peshu J, Faiz MA, Ghose A, Hossain MA, Samad R, Rahman MR, Hasan MM, Islam A, Miotto O, Amato R, MacInnis B, Stalker J, Kwiatkowski DP, Bozdech Z, Jeeyapant A, Cheah PY, Sakulthaew T, Chalk J, Intharabut B, Silamut K, Lee SJ, Vihokhern B, Kunasol C, Imwong M, Tarning J, Taylor WJ, Yeung S, Woodrow CJ, Flegg JA, Das D, Smith J, Venkatesan M, Plowe CV, Stepniewska K, Guerin PJ, Dondorp AM, Day NP, White NJ (2014) Tracking Resistance to Artemisinin Collaboration (TRAC). Spread of artemisinin resistance in Plasmodium falciparum malaria. N Engl J Med 371: 411-423.

8. Beshir KB, Sutherland CJ, Sawa P, Drakeley CJ, Okell L, Mweresa CK, Omar SA, Shekalaghe SA, Kaur H, Ndaro A, Chilongola J, Schallig HD, Sauerwein RW, Hallett RL, Bousema T (2013) Residual Plasmodium falciparum parasitemia in Kenyan children after artemisinin-combination therapy is associated with increased transmission to mosquitoes and parasite recurrence. $J$ Infect Dis 208: 2017-2024.

9. Henriques G, Hallett RL, Beshir KB, Gadalla NB, Johnson RE, Burrow R, van Schalkwyk DA, Sawa P, Omar SA, Clark TG, Bousema T, Sutherland CJ (2014) Directional selection at the pfmdrl, pfcrt, pfubpl, and pfap2mu loci of Plasmodium falciparum in Kenyan children treated with ACT. J Infect Dis 210: 2001-2008.

10. Muwanguzi J, Henriques G, Sawa P, Bousema T, Sutherland CJ, Beshir KB. (2016) Lack of K13 mutations in Plasmodium falciparum persisting after artemisinin combination therapy treatment of Kenyan children. Malar J 15: 36.

11. Yeka A, Kigozi R, Conrad MD, Lugemwa M, Okui P, Katureebe C, Belay K, Kapella BK, Chang MA, Kamya MR, Staedke SG, Dorsey G, Rosenthal PJ (2016) Artesunate/amodiaquine versus artemether/lumefantrine for the treatment of uncomplicated malaria in Uganda: a randomized trial. J Infect Dis 213: 1134-1142.

12. Sutherland CJ, Lansdell P, Sanders M, Muwanguzi J (2017) pfk13-independent treatment failure in four imported cases of Plasmodium falciparum malaria treated with artemether-lumefantrine in the United Kingdom. Antimicrob Agents Chemother 61: e02382-16.

13. Straimer J, Gnädig NF, Witkowski B, Amaratunga C, Duru V, Ramadani AP, Dacheux M, Khim 
bioRxiv preprint doi: https://doi.org/10.1101/621078; this version posted April 30, 2019. The copyright holder for this preprint (which was not certified by peer review) is the author/funder, who has granted bioRxiv a license to display the preprint in perpetuity. It is made available under aCC-BY-NC-ND 4.0 International license.

N, Zhang L, Lam S, Gregory PD, Urnov FD, Mercereau-Puijalon O, Benoit-Vical F, Fairhurst RM, menard, D, Fidock DA (2014) K13-propeller mutations confer artemisinin resistance in Plasmodium falciparum clinical isolates. Science 347: 428-431.

14. Demas AR, Sharma AI, Wong W, Early AM, Redmond S, Bopp S, Neafsey DE, Volkman SK, Hartl DL, Wirth DF (2018) Mutations in Plasmodium falciparum actin-binding protein coronin confer reduced artemisinin susceptibility. Proc Natl Acad Sci USA doi: 10.1073/pnas1812317115. [Epub ahead of print]

15. Hunt P, Afonso A, Creasey A, Culleton R, Sidhu AB, Logan J, Valderramos SG, McNae I, Cheesman S, do Rosario V, Carter R, Fidock DA, Cravo P (2007) Gene encoding a deubiquitinating enzyme is mutated in artesunate- and chloroquine-resistant rodent malaria parasites. Mol Microbiol 65: 27-40.

16. Henriques G, Martinelli A, Rodrigues L, Modrzynska K, Fawcett R, Houston DR, Borges ST, d'Alessandro U, Tinto H, Karema C, Hunt P, Cravo P (2013) Artemisinin resistance in rodent malaria--mutation in the AP2 adaptor $\mu$-chain suggests involvement of endocytosis and membrane protein trafficking. Malar $J$ 12: 118 .

17. Henriques G, van Schalkwyk DA, Burrow R, Warhurst DC, Thompson E, Baker DA, Fidock DA, Hallett RL, Flueck C, Sutherland CJ (2015) The mu-subunit of Plasmodium falciparum clathrinassociated adaptor protein 2 modulates in vitro parasite response to artemisinin and quinine. Antimicrob Agents Chemother 59: 2540-2547.

18. Park SY, Guo X (2014) Adaptor protein complexes and intracellular transport. Biosci Rep 34: $\mathrm{e} 00123$

19. Collins, B M, McCoy, A J, Kent, H M, Evans, P R \& Owen, D J (2002) Molecular architecture and functional model of the endocytic AP2 complex. Cell 109: 523-535.

20. Yap CC, Winckler B (2015) Adapting for endocytosis: roles for endocytic sorting adaptors in directing neural development. Front Cell Neurosci 9: 119.

21. Traub LM (2003) Sorting it out: AP-2 and alternate clathrin adaptors in endocytic cargo selection. J Cell Biol 163: 203-208.

22. Elliott DA, McIntosh MT, Hosgood HD 3rd, Chen S, Zhang G, Baevova P, Joiner KA (2008) Four distinct pathways of hemoglobin uptake in the malaria parasite Plasmodium falciparum. Proc Natl Acad Sci U S A 105: 2463-2468.

23. Bakar NA, Klonis N, Hanssen E, Chan C, Tilley L (2010) Digestive-vacuole genesis and endocytic processes in the early intraerythrocytic stages of Plasmodium falciparum. J Cell Sci 123: 441-450.

24. Klonis N, Creek DJ, Tilley L (2013) Iron and heme metabolism in Plasmodium falciparum and the mechanism of action of artemisinins. Curr Opin Microbiol 16: 722-727.

25. Zhang S, Gerhard GS (2008) Heme activates artemisinin more efficiently than hemin, inorganic iron, or haemoglobin. Bioorg Med Chem 16(16): 7853-7861.

26. Xie SC, Dogovski C, Hanssen E, Chiu F, Yang T, Crespo MP, Stafford C, Batinovic S, Teguh S, Charman S, Klonis N, Tilley L (2016) Haemoglobin degradation underpins the sensitivity of early ring stage Plasmodium falciparum to artemisinins. J Cell Sci 129: 406-416.

27. Witkowski B , Khim N, Chim P, Kim S, Ke S, Kloeung N, Chy S, Duong S, Leang R, Ringwald P, Dondorp AM, Tripura R, Benoit-Vical F, Berry A, Gorgette O, Ariey F, Barale JC, MercereauPuijalon O, Menard D (2013) Reduced artemisinin susceptibility of Plasmodium falciparum ring stages in western Cambodia Antimicrob Agents Chemother 57: 914-923.

28. Siddiqui G, Srivastava A, Russell AS, Creek DJ (2017) Multi-omics based identification of specific biochemical changes associated with pfkelch13-mutant artemisinin-resistant Plasmodium falciparum. J Infect Dis 215: 1435-1444.

29. Mok S, Ashley EA, Ferreira PE, Zhu L, Lin Z, Yeo T, Chotivanich K, Imwong M, Pukrittayakamee S, Dhorda M, Nguon C, Lim P, Amaratunga C, Suon S, Hien TT, Htut Y, Faiz MA, Onyamboko MA, Mayxay M, Newton PN, Tripura R, Woodrow CJ, Miotto O, Kwiatkowski DP, Nosten F, Day NP, Preiser PR, White NJ, Dondorp AM, Fairhurst RM, Bozdech Z. (2015) Population transcriptomics of human malaria parasites reveals the mechanism of artemisinin resistance. Science 347: 431-435.

30. Witkowski B, Khim N, Chim P, Kim S, Ke S, Kloeung N, Chy S, Duong S, Leang R, Ringwald P, Dondorp AM, Tripura R, Benoit-Vical F, Berry A, Gorgette O, Ariey F, Barale JC, MercereauPuijalon O, Menard D (2013) Novel phenotypic assays for the detection of artemisinin-resistant 
bioRxiv preprint doi: https://doi.org/10.1101/621078; this version posted April 30, 2019. The copyright holder for this preprint (which was not certified by peer review) is the author/funder, who has granted bioRxiv a license to display the preprint in perpetuity. It is made available under aCC-BY-NC-ND 4.0 International license.

Plasmodium falciparum malaria in Cambodia: In-vitro and ex-vivo drug-response studies. Lancet Infect Dis 13: 1043-1049.

31. Ménard D, Khim N, Beghain J, Adegnika AA, Amodu O, Barnadas C, Berry A, Boum Y, Bustos MDG, Cao J, Caridad J. Espino FE, Chen JH, Collet L, Cui L, Das Thakur G, Dieye A, Djallé DD, Dorkenoo MA, Eboumbou Moukoko C, Fall B, Fandeur T, Ferreira-da-Cruz MF, Fola AA, Fuehrer HP, Hassan AM, Herrera S, Hongvanthong B, Houzé S, Hua TL, Huy R, Jahirul Karim M, Jiang L, Kano S, Khan W, Khanthavong M, Kremsner PG, Lacerda M, Laminou IM, Leang R, Leelawong M, Lin K, Mazarati JB, Mei L, Menard S, Morlais I, Muhindo Mavoko H, Musset L, Na-Bangchang K, Nambozi M, Niaré K, Noedl H, Ouedraogo JB, Pillai DR, Pradines B, Quang Phuc B, Rahim Awab G, Ramharter M, Randrianarivelojosia M, Sattabongkot J, Shafiul Alam M, Sheikh Omar A, Silué KD, Sirima SB, Sutherland CJ, Syafruddin D, Tahar R, Toure OA, Tshibangu P, Vigan-Womas I, Warsame M, Wini L, Zakeri S, Kim S, Eam R, Berne L, Khean C, Chy S, Ken M, Loch K, Canier L, Duru V, Legrand E, Barale JC, Stokes B, Straimer J, Witkowski B, Fidock DA, Rogier C, Ringwald P, Ariey F, Mercereau-Puijalon O (2016) A worldwide map of Plasmodium falciparum K13-propeller polymorphisms. N Engl J Med 374: 2453-2464.

32. Yang T, Xie SC, Cao P, Giannangelo C, McCaw J, Creek DJ, Charman SA, Klonis N, Tilley L (2016) Comparison of the exposure time dependence of the activities of synthetic ozonide antimalarials and dihydroartemisinin against K13 wild-type and mutant Plasmodium falciparum strains. Antimicrob Agents Chemother 60: 4501-4510.

33. Henrici RC, van Schalkwyk DA, Sutherland CJ (2018) Transient temperature fluctuations severely decrease P. falciparum susceptibility to artemisinin in vitro. Int J Parasitol Drugs Drug Res 9: 2326.

34. Crary JL, Haldar K. (1992) Brefeldin A inhibits protein secretion and parasite maturation in the ring stage of Plasmodium falciparum. Mol Biochem Parasitol 53: 185-92.

35. Struck NS, de Souza Dias S, Langer C, Marti M, Pearce JA, Cowman AF, Gilberger TW. (2005) Re-defining the Golgi complex in Plasmodium falciparum using the novel Golgi marker PfGRASP. J Cell Sci 118: 5603-13.

36. Birnbaum J, Flemming S, Reichard N, Soares AB, Mesén-Ramírez P, Jonscher E, Bergmann B, Spielmann T (2017) A genetic system to study Plasmodium falciparum protein function. Nat Methods 14: 450-456.

37. Collins CR, Das S, Wong EH, Andenmatten N, Stallmach R, Hackett F, Herman JP, Müller S, Meissner M, Blackman MJ (2013) Robust inducible Cre recombinase activity in the human malaria parasite Plasmodium falciparum enables efficient gene deletion within a single asexual erythrocytic growth cycle. Mol Microbiol 88: 687-701.

38. Jones ML, Das S, Belda H, Collins CR, Blackman MJ, Treeck M (2016) A versatile strategy for rapid conditional genome engineering using loxP sites in a small synthetic intron in Plasmodium falciparum. Sci Rep 6: 21800.

39. Obado SO, Field MC, Chait BT, Rout MP (2016) High-efficiency isolation of nuclear envelope protein complexes from trypanosomes. Methods Mol Biol 1411: 67-80.

40. Nevin WD, Dacks JB (2009) Repeated secondary loss of adaptin complex genes in the Apicomplexa. Parasitol Int 58: 86-94.

41. Cerqueira GC, Cheeseman IH, Schaffner SF, Nair S, McDew-White M, Phyo AP, Ashley EA, Melnikov A, Rogov P, Birren BW, Nosten F, Anderson TJC, Neafsey DE (2017) Longitudinal genomic surveillance of Plasmodium falciparum malaria parasites reveals complex genomic architecture of emerging artemisinin resistance. Genome Biol 18: 78.

42. Kaderi Kibria KM, Rawat K, Klinger CM, Datta G, Panchal M, Singh S, Iyer GR, Kaur I, Sharma V, Dacks JB, Mohmmed A, Malhotra P (2015) A role for adaptor protein complex 1 in protein targeting to rhoptry organelles in Plasmodium falciparum. Biochim Biophys Acta 1853: 699-710.

43. Kalb LC, Frederico YC, Boehm C, Moreira CM, Soares MJ, Field MC (2016) Conservation and divergence within the clathrin interactome of Trypanosoma cruzi. Sci Rep 6: 31212.

44. Rao RV, Hermel E, Castro-Obregon S, del Rio G, Ellerby LM, Ellerby HM, Bredesen DE (2001) Coupling endoplasmic reticulum stress to the cell death program. Mechanism of caspase activation. J Biol Chem 276: 33869-33874.

45. Zhang M, Gallego-Delgado J, Fernandez-Arias C, Waters NC, Rodriguez A, Tsuji M, Wek RC, Nussenzweig V, Sullivan WJ Jr (2017) Inhibiting the Plasmodium eIF2 $\alpha$ kinase PK4 prevents 
bioRxiv preprint doi: https://doi.org/10.1101/621078; this version posted April 30, 2019. The copyright holder for this preprint (which was not certified by peer review) is the author/funder, who has granted bioRxiv a license to display the preprint in perpetuity. It is made available under aCC-BY-NC-ND 4.0 International license.

artemisinin-induced latency. Cell Host Microbe 22: 766-776.

46. Benting J, Mattei D, Lingelbach K. (1994) Brefeldin A inhibits transport of the glycophorinbinding protein from Plasmodium falciparum into the host erythrocyte. Biochem J 300: 821-6.

47. Rocamora F, Zhu L, Liong KY, Dondorp A, Miotto O, Mok S, Bozdech Z (2018) Oxidative stress and protein damage responses mediate artemisinin resistance in malaria parasites. PLoS Pathog 14: e1006930.

48. Boehm M, Bonifacino JS. (2001) Adaptins. The final recount. Mol Biol Cell 12: 2907-2920.

49. Bhattacharjee S, Coppens I, Mbengue A, Suresh N, Ghorbal M, Slouka Z, Safeukui I, Tang HY, Speicher DW, Stahelin RV, Mohandas N, Haldar K (2018) Remodeling of the malaria parasite and host human red cell by vesicle amplification that induces artemisinin resistance. Blood 131: 12341247.

50. Mbengue A, Bhattacharjee S, Pandharkar T, Liu H, Estiu G, Stahelin RV, Rizk SS, Njimoh DL, Ryan Y, Chotivanich K, Nguon C, Ghorbal M, Lopez-Rubio JJ, Pfrender M, Emrich S, Mohandas N, Dondorp AM, Wiest O, Haldar K (2015) A molecular mechanism of artemisinin resistance in Plasmodium falciparum malaria. Nature 520: 683-690.

51. Boddey JA, O'Neill MT, Lopaticki S, Carvalho TG, Hodder AN, Nebl T, Wawra S, van West P, Ebrahimzadeh Z, Richard D, Flemming S, Spielmann T, Przyborski J, Babon JJ, Cowman AF (2016) Export of malaria proteins requires co-translational processing of the PEXEL motif independent of phosphatidylinositol-3-phosphate binding. Nat Commun 7: 10470.

52. Breglio KF, Amato R, Eastman R, Lim P, Sa JM, Guha R, Ganesan S, Dorward DW, KlumppThomas C, McKnight C, Fairhurst RM, Roberts D, Thomas C, Simon AK. (2018) A single nucleotide polymorphism in the Plasmodium falciparum atg 18 gene associates with artemisinin resistance and confers enhanced parasite survival under nutrient deprivation. Malar J 17: 391.

53. Henrici RC, Sutherland CJ (2018) Alternative pathway to reduced artemisinin susceptibility in Plasmodium falciparum. Proc Natl Acad Sci U S A doi: 10.1073/pnas.1818287115. [Epub ahead of print]

54. Ghorbal M, Gorman M, Macpherson CR, Martins RM, Scherf A, Lopez-Rubio JJ (2014) Genome editing in the human malaria parasite Plasmodium falciparum using the CRISPR-Cas9 system. Nat Biotechnol 32: 819-821.

55. Deitsch K, Driskill C, Wellems T (2001) Transformation of malaria parasites by the spontaneous uptake and expression of DNA from human erythrocytes. Nucleic Acids Res 29: 850-853.

56. van Schalkwyk DA, Moon RW, Blasco B, Sutherland CJ (2017) Comparison of the susceptibility of Plasmodium knowlesi and Plasmodium falciparum to antimalarial agents. J Antimicrob Chemother 72: 3051-3058.

57. Cox J, Mann M. (2008) MaxQuant enables high peptide identification rates, individualized p.p.b.range mass accuracies and proteome-wide protein quantification. Nat Biotechno. 26, 1367-1372.

58. Cox J, Hein MY, Luber CA, Paron I, Nagaraj N, Mann M. (2014) Accurate proteome-wide labelfree quantification by delayed normalization and maximal peptide ratio extraction, termed MaxLFQ. Mol Cell Proteomics 13: 2513-2526.

59. Tyanova S, Temu T, Sinitcyn P, Carlson A, Hein MY, Geiger T, Mann M, Cox J. (2016) The Perseus computational platform for comprehensive analysis of (prote)omics data. Nat Methods 13: 731-740. 
bioRxiv preprint doi: https://doi.org/10.1101/621078; this version posted April 30, 2019. The copyright holder for this preprint (which was not certified by peer review) is the author/funder, who has granted bioRxiv a license to display the preprint in perpetuity. It is made available under aCC-BY-NC-ND 4.0 International license.

\section{Figure Legends}

\section{Figure 1. Gene-editing of $p f a p 2 m u$ and artemisinin susceptibility by $\mathbf{R S A}^{\text {th }}$}

A CRISPR-Cas9 editing was used to install the pfap2mu(I592T) variant codon (red, left) and pfap $2 m u(S 160 N)$ variant codon (blue, right) into the endogenous locus. The pictured homologous repair constructs were modified to also introduce the I592I wild-type codon in the context of silent mutations ablating the Cas9 PAM site, as a control for their impact on phenotype. Primers used for genotype mapping anneal outside of the homologous repair template as depicted (P1 and P2; Suppl. Table 1). Recodonised sequence near alternate I592 codons (red) also includes a SpeI restriction site, and recodonised sequence near S160 codons (blue) ablates an SnaBI restriction site for downstream PCR-RFLP mapping.

B Clones of parasite lines expressing AP- $2 \mu$ (I592T), AP-2 $\mu$ (I592I), and AP- $2 \mu(\mathrm{S} 160 \mathrm{~N})$ were generated by limiting dilution and confirmed by PCR-RFLP genotype mapping (with SpeI or SnaBI restriction endonuclease) and Sanger sequencing. Amplification of the locus with P1 and P2 produces a 2247 bp fragment; For I592 transgenic parasites, SpeI digestion of an amplicon containing the transgenic locus liberates a $301 \mathrm{bp}$ fragment. The wild-type amplicon is not cleaved. For S160 transgenic parasites, SnaBI does not cleave the transgenic amplicon, while wild-type amplicons liberate a $789 \mathrm{bp}$ fragment. MW: fragment length in kilobases.

C $\quad \mathrm{RSA}^{4 \mathrm{~h}}$ susceptibility to artemisinin (DHA) of mutant and parental parasite lines, presented as percent survival, compared to untreated control, following a $4 \mathrm{~h}$ pulse of $700 \mathrm{nM}$ dihydroartemisinin. The Cam3.II-family of parasite lines harbour pfkelch13 mutations (as indicated $)^{13}$. Cam3.II ${ }^{\text {REV }}$ expresses wild-type pfkelch13. Mean of at least four biological replicates is shown for each line, each performed in technical duplicate, with standard error. Each technical replicate enumerates 100,000 gate-stopping events. P values derived from MannWhitney non-parametric test, comparing each parasite line to 3D7.

D $\mathrm{EC}_{50}$ estimates $(\mathrm{nM})$ for clones of each mutant and the 3D7 parent were derived from $48 \mathrm{~h}$ exposures to the drugs named across a range of concentrations. Each data point shows the mean of at least four biological replicates, performed in technical duplicate, with standard error. Bold face indicates $\mathrm{P}<0.05$ (Mann-Whitney $\mathrm{U}$ test), compared to $\mathrm{EC}_{50}$ estimate for 3D7.

NS: not significant; ***: $\mathrm{P}<0.005$.

Figure 2. Plasmodium falciparum AP-2 $\mu$ is localised to a non-canonical cytoplasmic compartment

A Modifications to the homologous repair construct used to install AP-2 $\mu$ variants (Fig. 1) to fuse a tandem triple haemagglutinin tag (3xHA) onto the C-terminus of AP- $2 \mu$.

B PCR-based genotyping of two parasite clones harbouring AP- $2 \mu-3 \times$ HA in place of the endogenous AP- $2 \mu$ allele. Amplification of the integrated transgenic pfap $2 m u$ locus with $\mathrm{P} 3$ and P2 (annealing sites annotated) produces an $862 \mathrm{bp}$ fragment. Genotypes were confirmed by Sanger sequencing of the PCR products shown.

C Anti-HA western blot confirming expression of the desired fusion protein (approx. $78 \mathrm{kDa}$ ) in mixed-stage lysates, compared to wild-type parental 3D7. MW presented in kDa.

D Localisation of AP- $2 \mu-3 \times$ HA (green) across the asexual life cycle by anti-HA IFA, counterstained for parasite DNA with DAPI (blue). Images shown are representative of more than 100 cells examined at each stage; merge is the superimposition of each channel on a brightfield image.

E Immunoelectron micrograph of a representative young intra-erythrocytic trophozoite. AP- $2 \mu$ $3 \times$ HA parasites probed with an anti-HA rabbit antibody and a secondary antibody $18 \mathrm{~nm}$ gold 
bioRxiv preprint doi: https://doi.org/10.1101/621078; this version posted April 30,2019. The copyright holder for this preprint (which was not certified by peer review) is the author/funder, who has granted bioRxiv a license to display the preprint in perpetuity. It is made available under aCC-BY-NC-ND 4.0 International license.

conjugate. Protein disulphide isomerase (PDI), a marker for the parasite ER, is detected by an anti-PDI mouse antibody and a secondary conjugated to $12 \mathrm{~nm}$ gold particles. C: cytostome; $\mathrm{N}$ : nucleus; ER: endoplasmic reticulum; White Arrowheads: AP- $2 \mu$ at nuclear membrane; Black Arrowheads: AP- $2 \mu$ associated with vesicles; Black Arrows: AP- $2 \mu$ near the ER. Scale bar: 500 nm.

F Localisation of AP-2 $\mu-3 \times$ HA (false-coloured green) with respect to ectopically-expressed GFPK13 (false-coloured red) across the asexual life cycle by IFA. Representative images of more than 100 observed cells is shown.

\section{Figure $3 \quad$ AP-2 $\mu$ is required for asexual replication and schizont maturation}

A Schematic for the integration of loxP recombination elements into the endogenous pfap2mu locus of a parasite line constitutively expressing a split-Cre recombinase ${ }^{33}$. Addition of rap initiates Cre dimerisation and excision of the loxP-flanked (floxed) region of pfap $2 m u$ on chromosome 12.

B PCR confirmation of rap-induced excision of floxed region by PCR using primers P4 and P5 (panel A).

C Western blot confirmation that excision of floxed pfap $2 m u$ causes a loss of AP-2 $\mu-3 x$ HA protein (within 24h) but has no effect on levels of CDC48 protein. MW presented in $\mathrm{kDa}$.

D Parasite multiplication in the 3D7-AP-2 $\mu$-floxed-3xHA line across 2.5 cell cycles, with and without rap induction of Cre. Mean parasitaemia (normalised to $0.25 \%$ starting parasitaemia) with standard error is shown at each time point. Each data point represents the average of at least three biological replicates.

E PCR confirmation of rap-mediated pfap $2 m u$ excision in 3D7-AP-2 $\mu$-floxed-3xHA parasites transfected with an episome encoding cam-AP- $2 \mu$-GFP. Construction of this complementation plasmid is described elsewhere (R. Henrici, PhD Thesis, University of London 2018).

F Western blot confirmation that excision of chromosomal pfap $2 m u$ from 3D7-AP-2 $\mu$-floxed$3 \times \mathrm{xHA} / \mathrm{cam}$-AP- $2 \mu$-GFP parasites causes a loss of AP- $2 \mu-3 \mathrm{xHA}$ protein but does not prevent episomal expression of AP- $2 \mu-\mathrm{GFP}$.

G Parasite multiplication in the 3D7-AP- $2 \mu$-floxed-3xHA/cam-AP- $2 \mu$-GFP line across 2.5 cell cycles, with and without rap induction of Cre. Mean and standard error are shown as in panel D.

H Giemsa staining of 3D7-AP-2 $\mu$-floxed-3xHA schizonts, with and without rap treatment.

I Electron micrograph of 3D7-AP-2 $\mu$-floxed-3xHA schizonts, with and without $1 \mathrm{~h}$ ring-stage treatment with $10 \mathrm{nM}$ rap. Micronemes at the apical end of developing merozoites are labelled with arrowheads; asterisks indicate membrane separation. FV: food (digestive) vacuole; $\mathrm{H}$ : haemozoin; L: lipid body; M: merozoite; R: rhoptry. Scale bar: $500 \mathrm{~nm}$.

\section{Figure 4. Identification of AP-2 $\mu$-interacting proteins}

A Volcano plot from $p$-values versus the corresponding $t$-test difference of proteins identified by immunoprecipitation (IP) in Triton buffer. Cut-off curves for statistically significant interactors (dotted curve) were calculated from the estimated false discovery rate (for details see Methods). Selected hits are labelled (potentially non-specific interactors are in grey).

B Volcano plot for proteins identified by IP in CHAPS buffer.

C Table of selected identified interactors listing functional annotation, enrichment ratios (compared to controls; see Materials and Methods) and negative $\log _{10}$ of corresponding $p$-values for Triton \& CHAPS buffers, respectively. Additional hits are listed in Suppl. Table 2.

D $p f k 10$-GFP (left panel) or GFP alone (right panel), driven by the calmodulin promoter, were expressed episomally in 3D7-AP-2 $\mu-3 \times$ HA parasites and immunoprecipitated with $\alpha$-GFP 
bioRxiv preprint doi: https://doi.org/10.1101/621078; this version posted April 30,2019 . The copyright holder for this preprint (which was not certified by peer review) is the author/funder, who has granted bioRxiv a license to display the preprint in perpetuity. It is made available under aCC-BY-NC-ND 4.0 International license.

antibody coated magnetic beads. Western blots of fractionated proteins are shown, probed with either $\alpha$-GFP or $\alpha$-HA antibodies. MW presented in kDa.

\section{Figure 5: $\quad P$. falciparum AP-2 $\mu$ does not interact with clathrin heavy chain}

A Western blot of mixed stage 3D7-CHC-2xFKBP-GFP lysates probed with antibodies; either $\alpha$ GFP (left) or $\alpha$-PfCHC (right).

B Volcano plot from $p$-values versus the corresponding $t$-test difference of proteins identified by $\alpha$ GFP (nanobody) immunoprecipitation in CHAPS buffer. Cut-off curves for statistically significant interactors (dotted curve) were calculated from the estimated false discovery rate.

C Table of abundances and enrichment ratio for subunits of all adaptor protein complex subunits identified in the $\alpha$-CHC-GFP pulldown. ND indicates no peptides were detected that correspond to the listed protein.

D Western blot of $\alpha$-PfCHC immunoprecipitation performed on cryomilled 3D7-AP-2 $\mu-3 x H A$ trophozoite lysates. Membrane was probed with $\alpha-\mathrm{PfCHC}$ and $\alpha-\mathrm{HA}$ antibodies.

E Maximum intensity projection IFA of representative trophozoite and schizont stages of 3D7-AP$2 \mu$-3xHA parasites, from among at least 100 cells examined at each stage, probed with both $\alpha-$ $\mathrm{PfCHC}$ and $\alpha-\mathrm{HA}$ antibodies, which are red and green in the merge images, respectively.

F Representative maximum intensity projection images of time-lapse live microscopic observation of CHC-2xFKBP-GFP in a trophozoite. Each frame represents the passage of 6 minutes.

Figure 6: Activation of the cell stress response with BFA induces artemisinin resistance in vitro

A Schematic representation of $\mathrm{BFA}^{5 \mathrm{~h}}-\mathrm{RSA}^{4 \mathrm{~h}}$ assay. Synchronous cultures of 3D7 parasites received $1 \mathrm{~h}$ pre-treatment with $5 \mu \mathrm{g} \mathrm{ml}^{-1} \mathrm{BFA}$ (green) before addition of DHA for the $\mathrm{RSA}^{4 \mathrm{~h}}$ (red).

B Relative proliferation of wild-type 3D7 parasites treated with $5 \mu \mathrm{g} \mathrm{ml}^{-1} \mathrm{BFA}^{5 \mathrm{~h}}$ compared to untreated parasites, in the absence of DHA.

C Western blot of parasite lysates probed with anti-eIF2 $\alpha$-P or anti-eIF2 $\alpha$, in BFA ${ }^{5 \mathrm{~h}}$-treated compared to solvent-treated cultures. Phosphorylation of eIF2 $\alpha$ indicates activation of the cell stress response.

D Parasite survival (\% of untreated) in $\mathrm{BFA}^{5 \mathrm{~h}}-\mathrm{RSA}^{4 \mathrm{~h}}$ and standard $\mathrm{RSA}^{4 \mathrm{~h}}$ in $3 \mathrm{D} 7$ parasites. Mean survival estimates \pm standard error for 3 experiments, each in technical duplicate, is shown. 
bioRxiv preprint doi: https://doi org/10.1101/621078; this version posted April 30,2019 . The copyright holder for this preprint (which was not certified by peer review) is the author/funder, who has granted bioRxiv a license to display the preprint in perpetuity. It is made available under aCC-BY-NC-ND 4.0 International license.

A

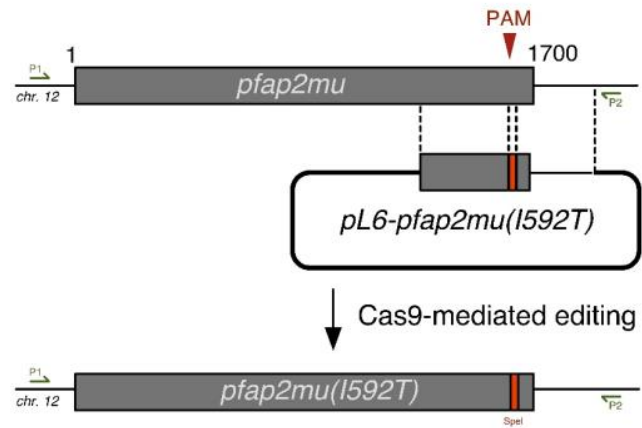

B

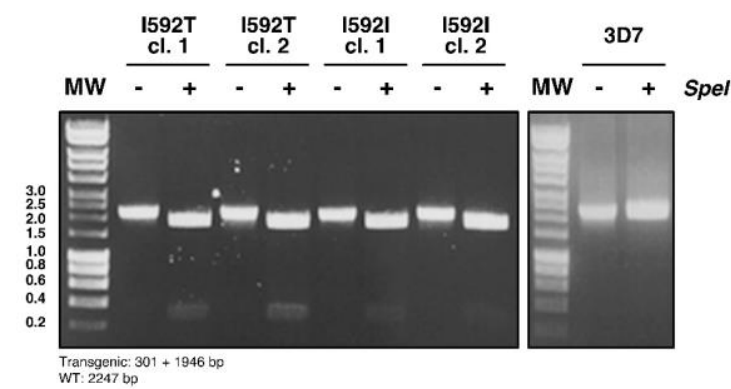

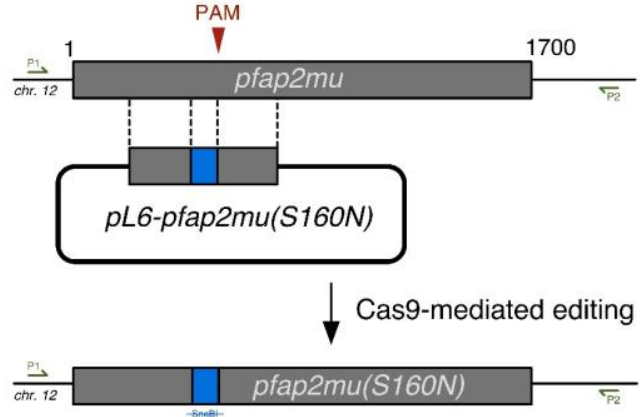

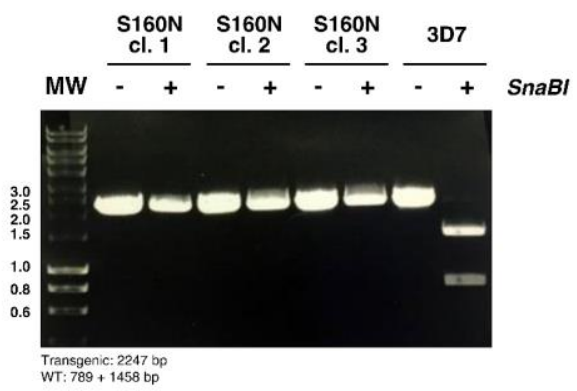

C

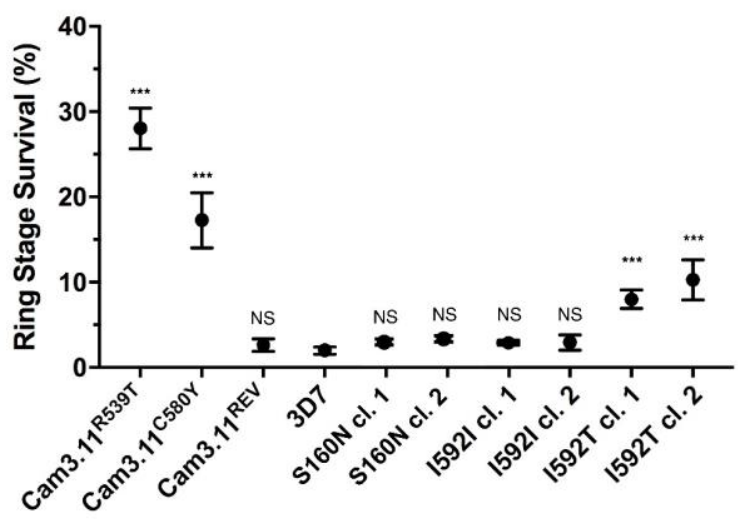

D

\begin{tabular}{|c|c|cc|cc|cc|}
\hline & $3 \mathrm{D} 7$ & $\mathrm{~S} 160 \mathrm{~N}$ cl $1 \mathrm{~S} 160 \mathrm{~N} \mathrm{cl} 2$ & $15921 \mathrm{cl} 1$ & $15921 \mathrm{cl} 2$ & I592Tcl 1 & I592T cl 2 \\
\hline Chloroquine & $13.7 \pm 0.3$ & $13.5 \pm 0.1$ & $14.9 \pm 0.4$ & $11.4 \pm 0.8$ & $12.3 \pm 0.4$ & $8.7 \pm 0.9$ & $\mathbf{7 . 4} \pm \mathbf{0 . 3}$ \\
\hline Quinine & $31.4 \pm 2.6$ & $27.7 \pm 2.0$ & $32.3 \pm 3.3$ & $23.4 \pm 2.5$ & $24.0 \pm 2.7$ & $24.8 \pm 1.9$ & $23.0 \pm 2.3$ \\
\hline DHA & $3.4 \pm 0.3$ & $2.9 \pm 0.2$ & $2.7 \pm 0.7$ & $2.8 \pm 0.6$ & $3.1 \pm 0.7$ & $3.1 \pm 0.7$ & $2.5 \pm 0.4$ \\
\hline Lumefantrine & $30.0 \pm 4.0$ & $26.9 \pm 2.7$ & $29.6 \pm 3.0$ & $30.2 \pm 3.0$ & $31.4 \pm 2.3$ & $20.9 \pm 2.1$ & $21.8 \pm 1.0$ \\
\hline Piperaquine & $31.6 \pm 4.5$ & $28.0 \pm 3.1$ & $29.6 \pm 5.0$ & $23.5 \pm 3.6$ & $25.9 \pm 0.7$ & $26.5 \pm 3.0$ & $22.8 \pm 2.5$ \\
\hline Mefloquine & $12.2 \pm 0.2$ & $12.1 \pm 0.5$ & $12.0 \pm 0.7$ & $16.8 \pm 2.4$ & $17.0 \pm 1.4$ & $16.2 \pm 1.8$ & $16.0 \pm 1.9$ \\
\hline
\end{tabular}

Figure 1. Gene-editing of pfap2mu and artemisinin susceptibility by RSA ${ }^{4 h}$ 
bioRxiv preprint doi: https://doi org/10.1101/621078; this version posted April 30,2019 . The copyright holder for this preprint (which was not certified by peer review) is the author/funder, who has granted bioRxiv a license to display the preprint in perpetuity. It is made available under aCC-BY-NC-ND 4.0 International license.

A

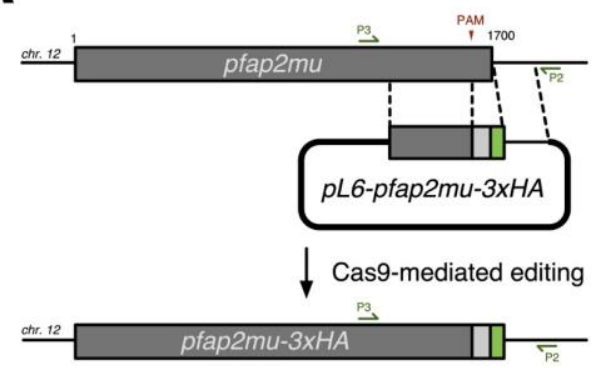

B $\frac{307-\mu 2 \cdot-3 \mathrm{xHA}}{\mathrm{cl} .1 \mathrm{cl} .2}$
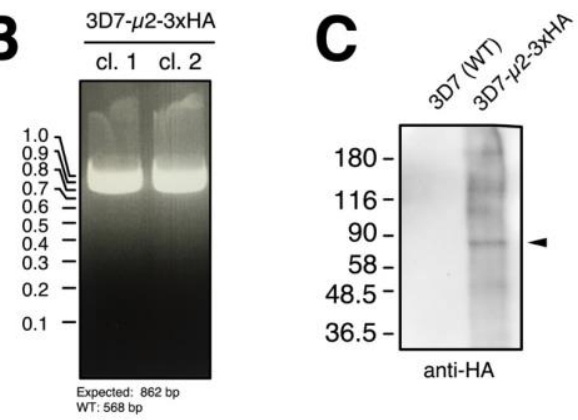

D

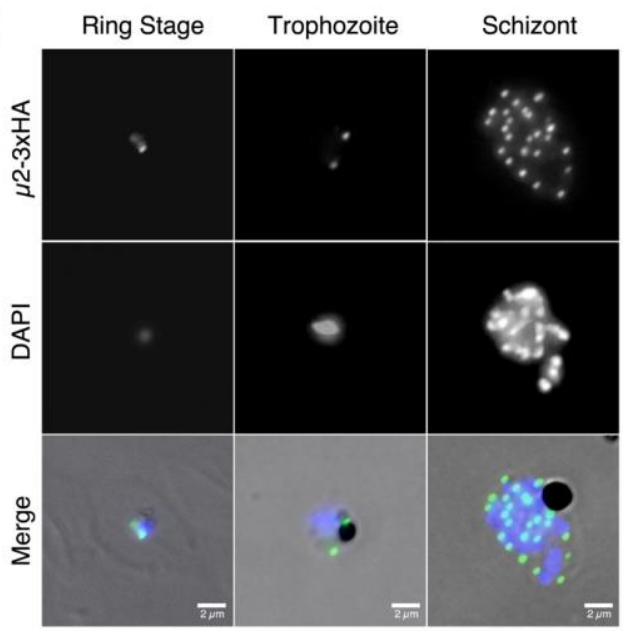

$\mathbf{E}$

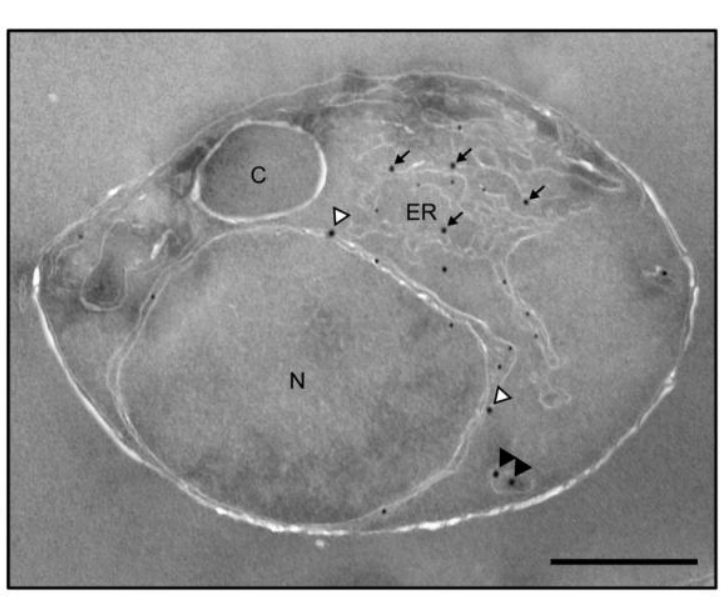

$\mathbf{F}$

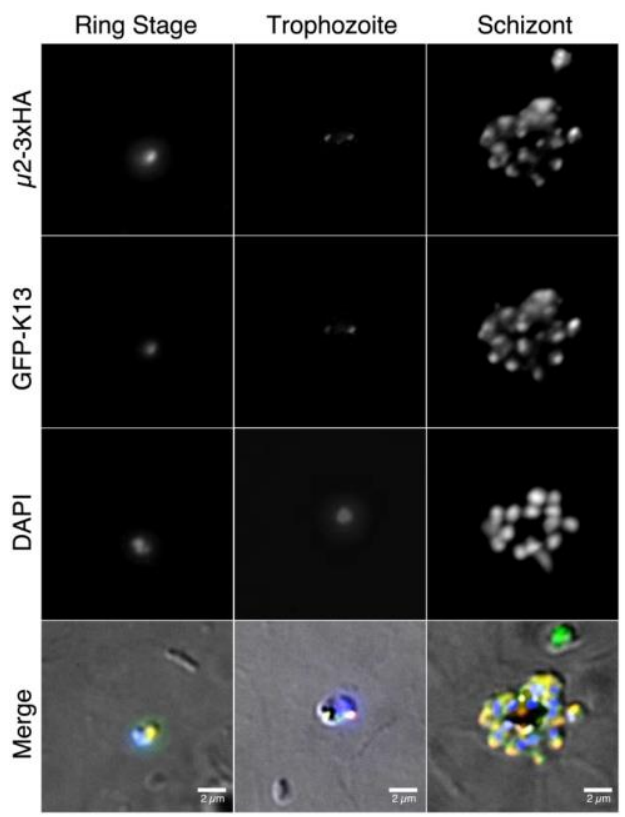

Figure 2. Plasmodium falciparum AP-2 $\mu$ is localised to a non-canonical cytoplasmic compartment 
A
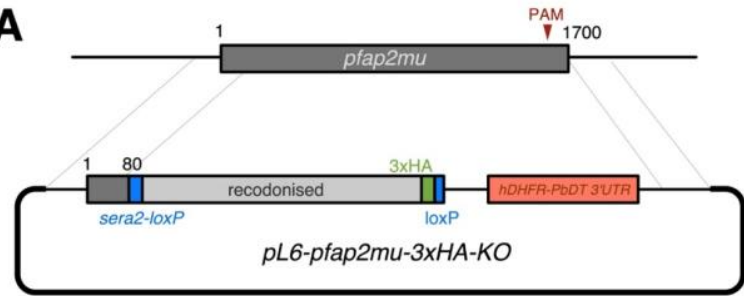

$\downarrow$ Cas9-mediated editing

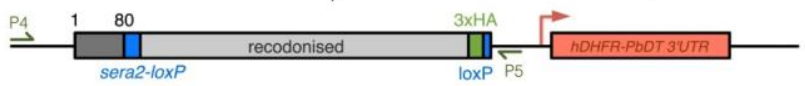

$\downarrow$ Cre-mediated excision
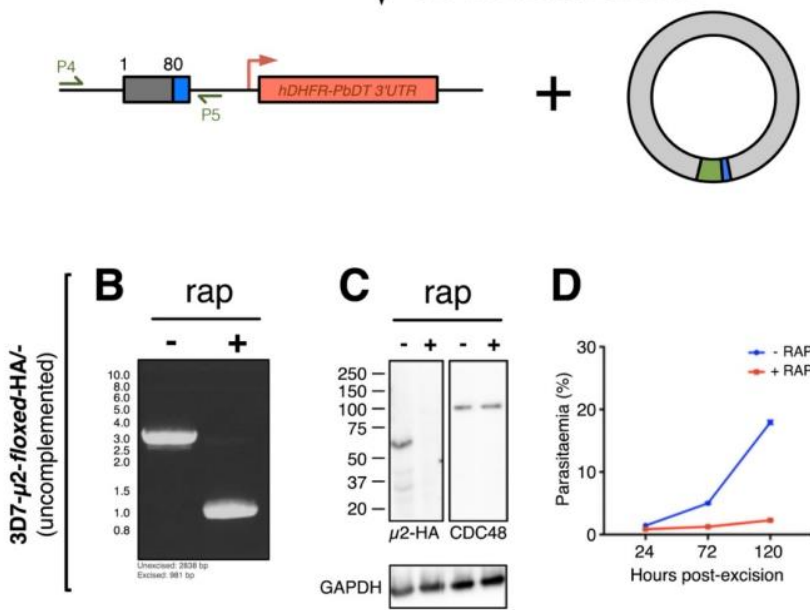

D

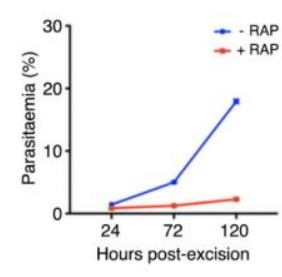

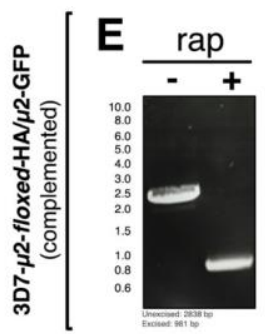

\section{G}

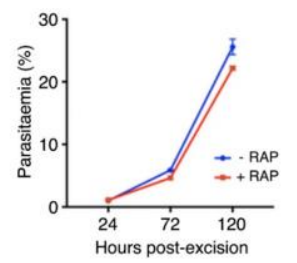

H
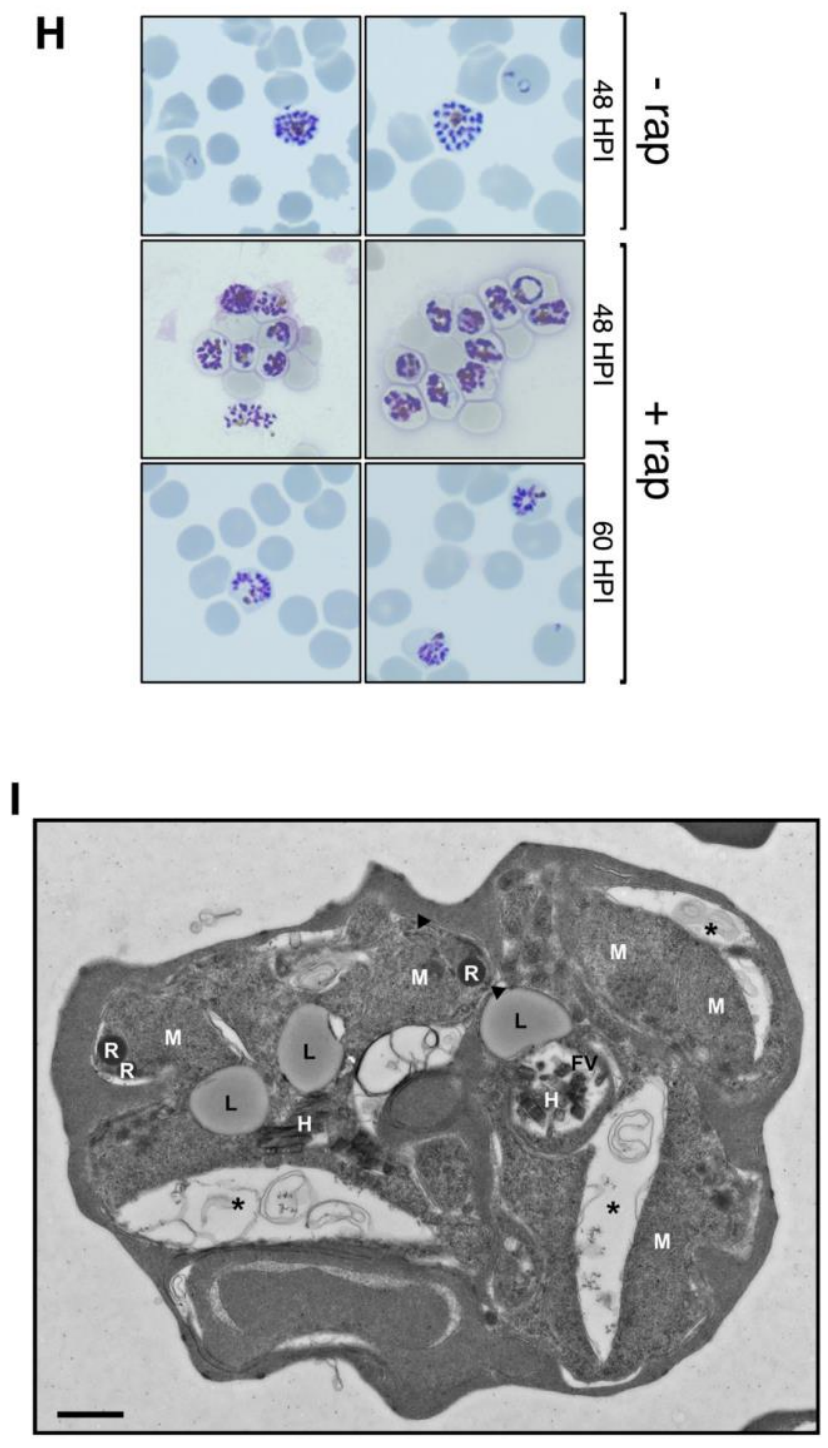

Figure 3. AP-2 $\mu$ is required for asexual replication and schizont maturation 
A

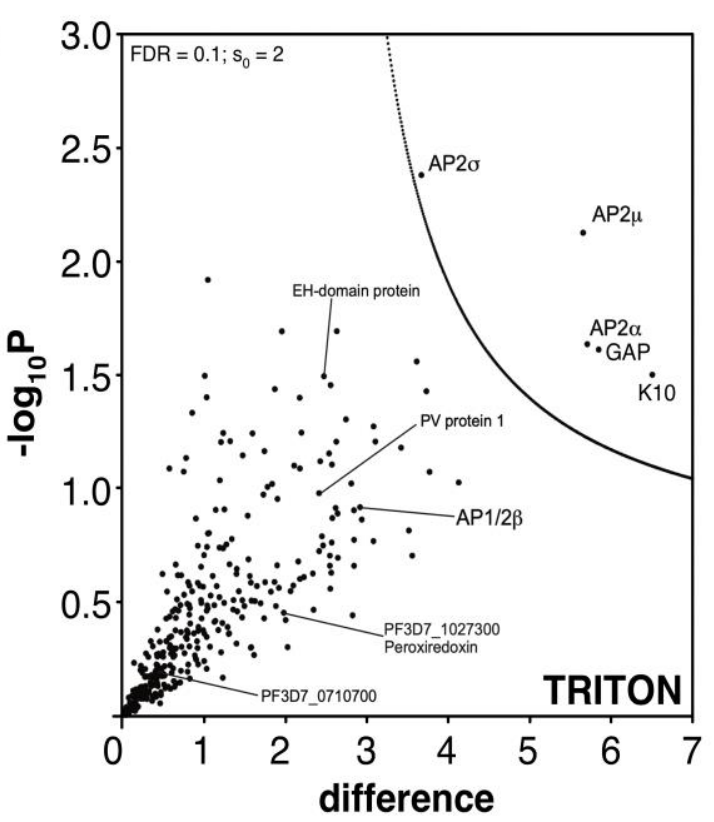

C

\begin{tabular}{|lc|cc|cc|}
\hline $\begin{array}{l}\text { Protein } \\
\text { Kelch 10 }\end{array}$ & Function & ratio & $-\log _{10}$ p & ratio & $-\log _{10} p$ \\
$\begin{array}{l}\text { PF3D7_1022600 } \\
\text { GTPase activating protein } \\
\text { PF3D7_1114200 }\end{array}$ & Unknown & 19.5 & 1.5 & 0.1 & 0.4 \\
$\begin{array}{l}\text { EH-domain protein } \\
\text { PF3D7_0304200 }\end{array}$ & Unknown & 21.8 & 1.6 & $\infty$ & 1 \\
$\begin{array}{l}\text { AP2 } \boldsymbol{\mu} \text {-subunit } \\
\text { PF3D7_1218300 }\end{array}$ & Traffic & 4.4 & 1.5 & $\infty$ & 0.3 \\
$\begin{array}{l}\text { AP2 } \sigma \text {-subunit } \\
\text { PF3D7_0217300 }\end{array}$ & Traffic \\
$\begin{array}{l}\text { AP2 a-subunit } \\
\text { PF3D7_0617100 }\end{array}$ & Traffic & 17.1 & 2.5 & $\infty$ & 0.9 \\
$\begin{array}{l}\text { AP1/2 } \beta \text {-subunit } \\
\text { PF3D7_0528100 }\end{array}$ & Traffic & 21 & 1.6 & 240.8 & 1 \\
$\begin{array}{l}\text { PV Protein 1 } \\
\text { PF3D7_1129100 }\end{array}$ & Traffic & 3.5 & 0.9 & 26.1 & 0.8 \\
$\begin{array}{l}\text { PTEX150 } \\
\text { PF3D7_1436300 }\end{array}$ & Periphery/Export & 3.5 & 1 & 11.6 & 0.8 \\
\hline
\end{tabular}

B

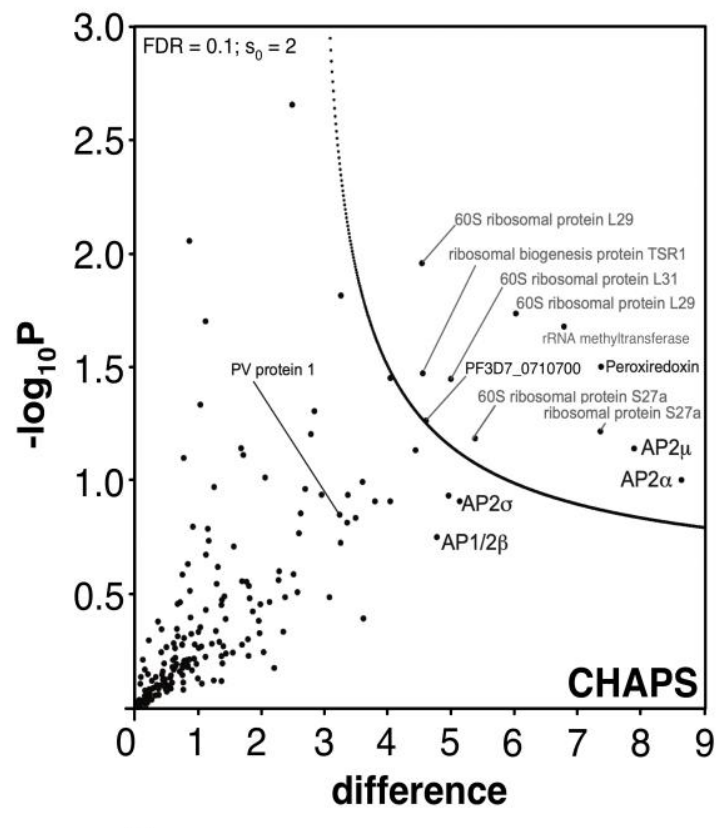

D
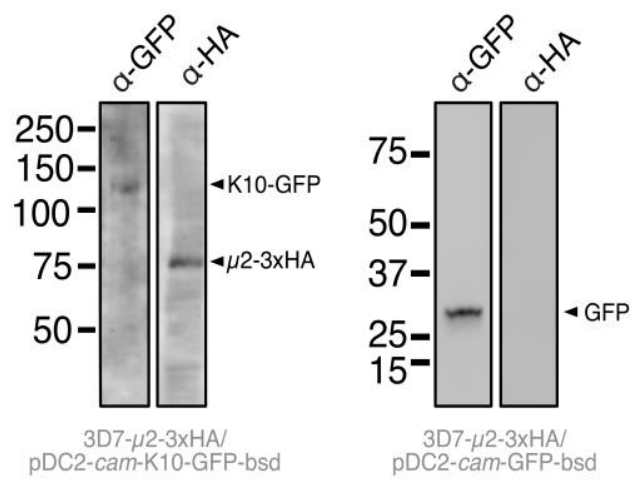

Figure 4. Identification of AP-2 $\mu$-interacting proteins 
bioRxiv preprint doi: https://doi org/10.1101/621078; this version posted April 30,2019 . The copyright holder for this preprint (which was not certified by peer review) is the author/funder, who has granted bioRxiv a license to display the preprint in perpetuity. It is made available under aCC-BY-NC-ND 4.0 International license.

A

$3 D 7$

(PfCHC-2xFKBP-GFP)

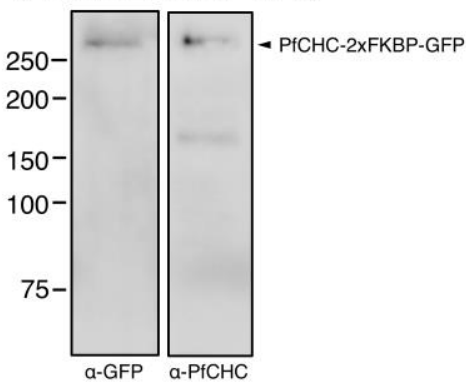

B

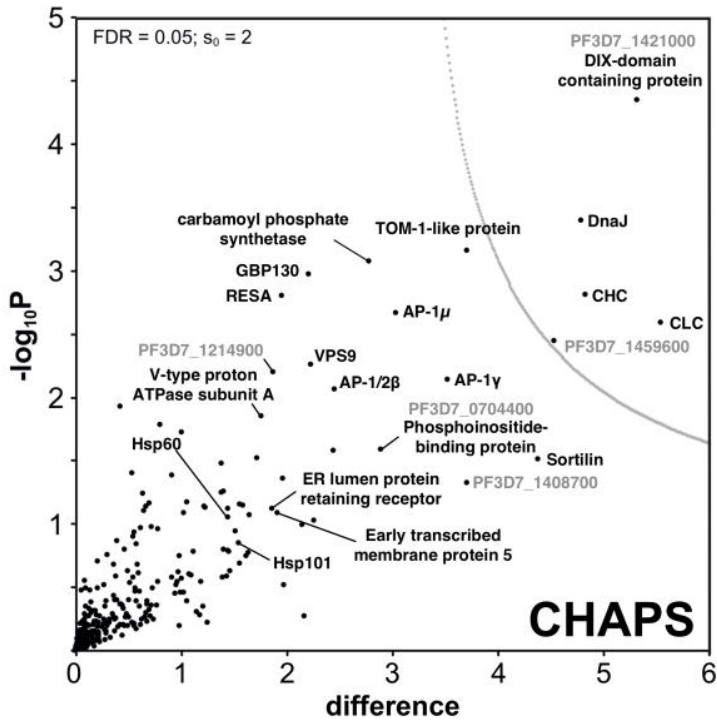

C

\begin{tabular}{|c|c|c|c|c|c|}
\hline Protein Name & PFID & $\begin{array}{l}\text { Average LFQ - wt } \\
\qquad(\mathrm{N}=3)\end{array}$ & $\begin{array}{c}\text { Average LFQ - GFP } \\
(\mathrm{N}=4)\end{array}$ & Enrichment & $-\log (P)$ \\
\hline clathrin heavy chain & PF3D7_1219100 & $3.07 \varepsilon+09$ & $6.87 E+10$ & 22.38 & 281 \\
\hline clathrin light chain & PF3D7_1435500 & $7.17 E+07$ & 2.19E+09 & 30.56 & 274 \\
\hline AP-1 complex subunit beta & PF3D7_1440700 & $1.25 E+08$ & $5.69 E+08$ & 4.56 & 2.06 \\
\hline AP-1 complex subunit gamma & PF307_0528100 & $7.43 E+07$ & $6.48 E+08$ & 8.72 & 2.27 \\
\hline AP-1 complex subunit mu & PF307_1455500 & $2.93 E+07$ & 3.18E +08 & 10.85 & 2.42 \\
\hline AP-1 complex subunit sigma & PF3D7_1311400 & ND & $290 E+07$ & $\infty$ & 0.15 \\
\hline AP-2 complex subunit alpha & PF3D7_0617100 & ND & ND & . & - \\
\hline AP-2 complex subunit mu & PF307_1218300 & ND & ND & - & - \\
\hline AP-2 complex subunit sigma & PF307_1118100 & ND & ND & - & - \\
\hline AP-3 complex subunit beta & PF307_0613500 & 1.1.13E+08 & $9.82 E+07$ & 0.87 & 0.01 \\
\hline AP- 3 complex subunit delta & PF307_0808100 & $7.85 E+07$ & $6.11 E+07$ & 0.78 & 0.10 \\
\hline AP- 3 complex subunit mu & PF307_1440700 & $1.34 E+08$ & $1.14 E+08$ & 0.85 & 0.04 \\
\hline AP-3 complex subunit sigma & PF3D7_1250500 & ND & $269 E+06$ & $\infty$ & 0.72 \\
\hline AP-4 complex subunit beta & PF307_0730200 & ND & ND & - & - \\
\hline AP-4 complex subunit epsilon & PF307_0904100 & ND & ND & . & - \\
\hline AP-4 complex subunit mu & PF3D7_1119500 & ND & ND & . & . \\
\hline
\end{tabular}

E

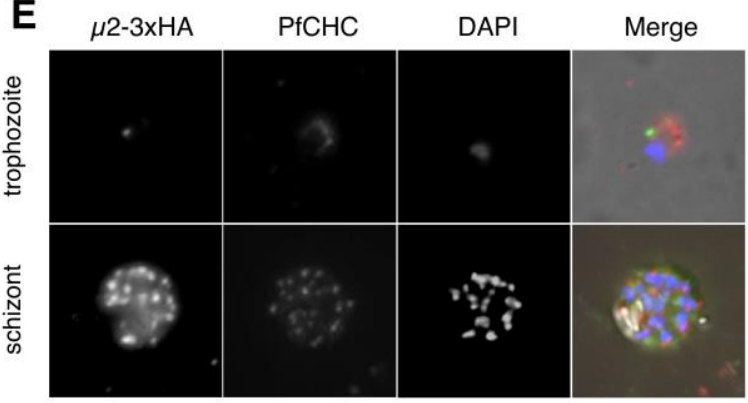

D

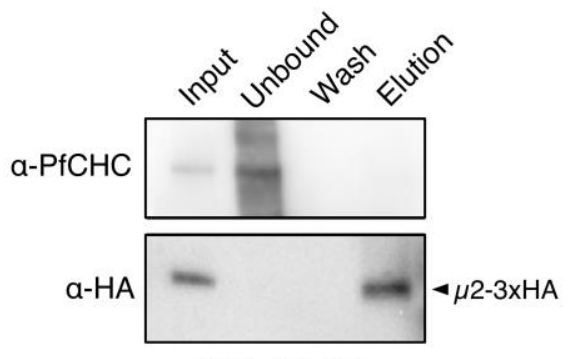

$3 \mathrm{D} 7-\mu 2-3 \times \mathrm{HA}$

$\mathbf{F}$

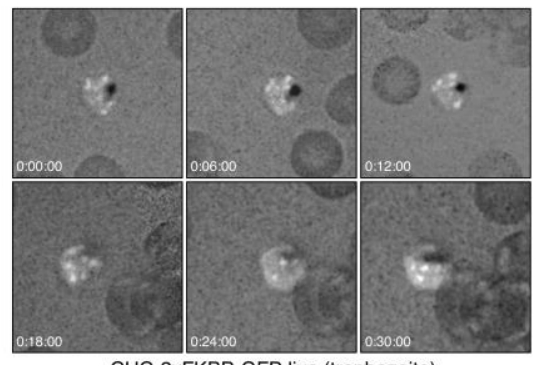

CHC-2xFKBP-GFP live (trophozoite)

Figure 5. P. falciparum AP-2 $\mu$ does not interact with clathrin heavy chain 
A

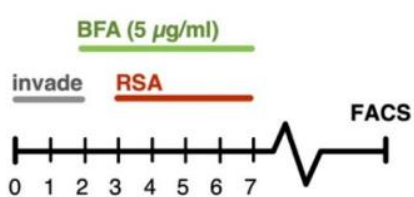

B

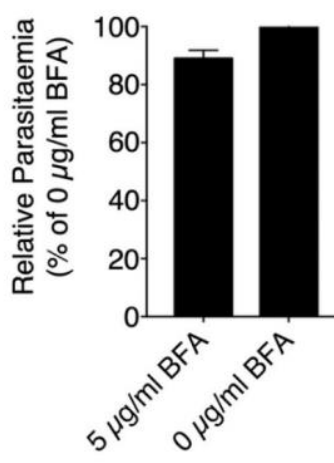

C

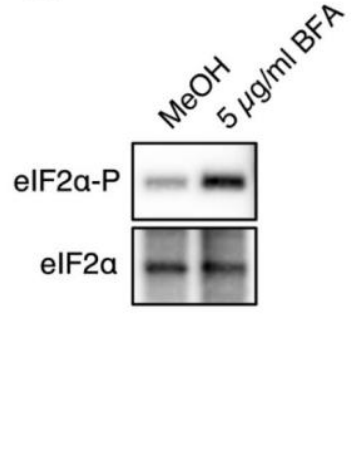

D

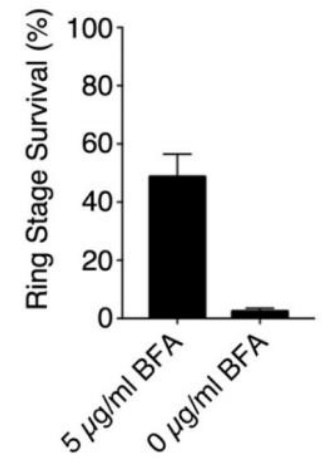

Figure 6. Activation of the cell stress response with BFA induces artemisinin resistance in vitro 


\section{SUPPLEMENTARY INFORMATION}
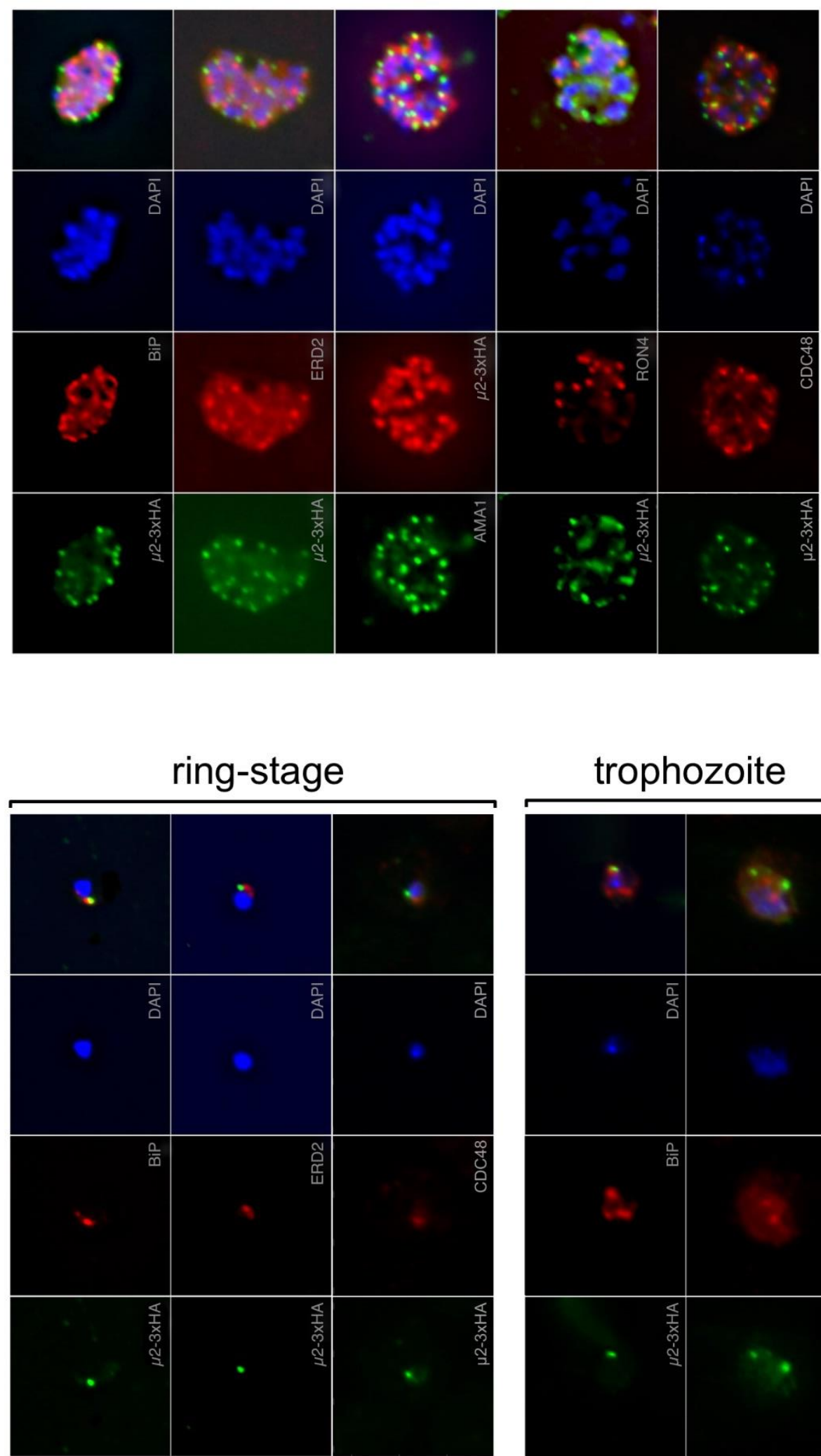

trophozoite

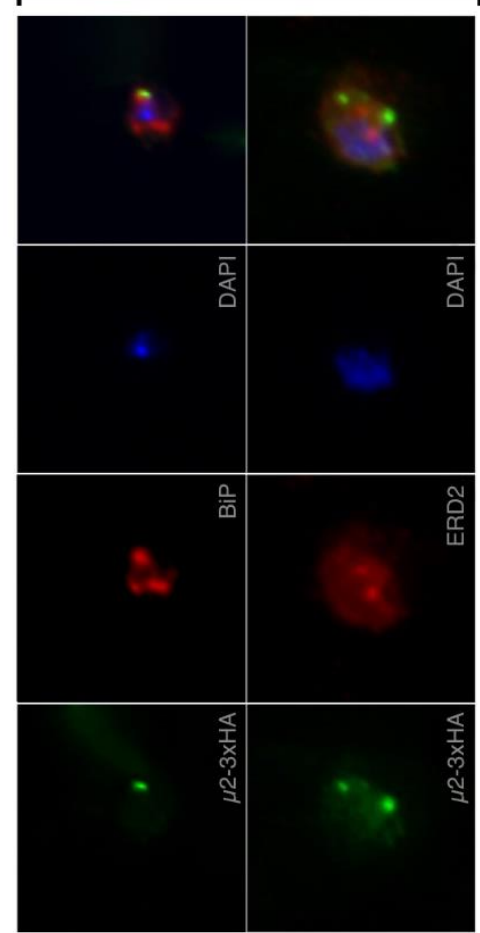

Suppl. Fig. 1. Localisation of AP-2 $\mu-3 \times$ HA with respect to cellular landmarks 

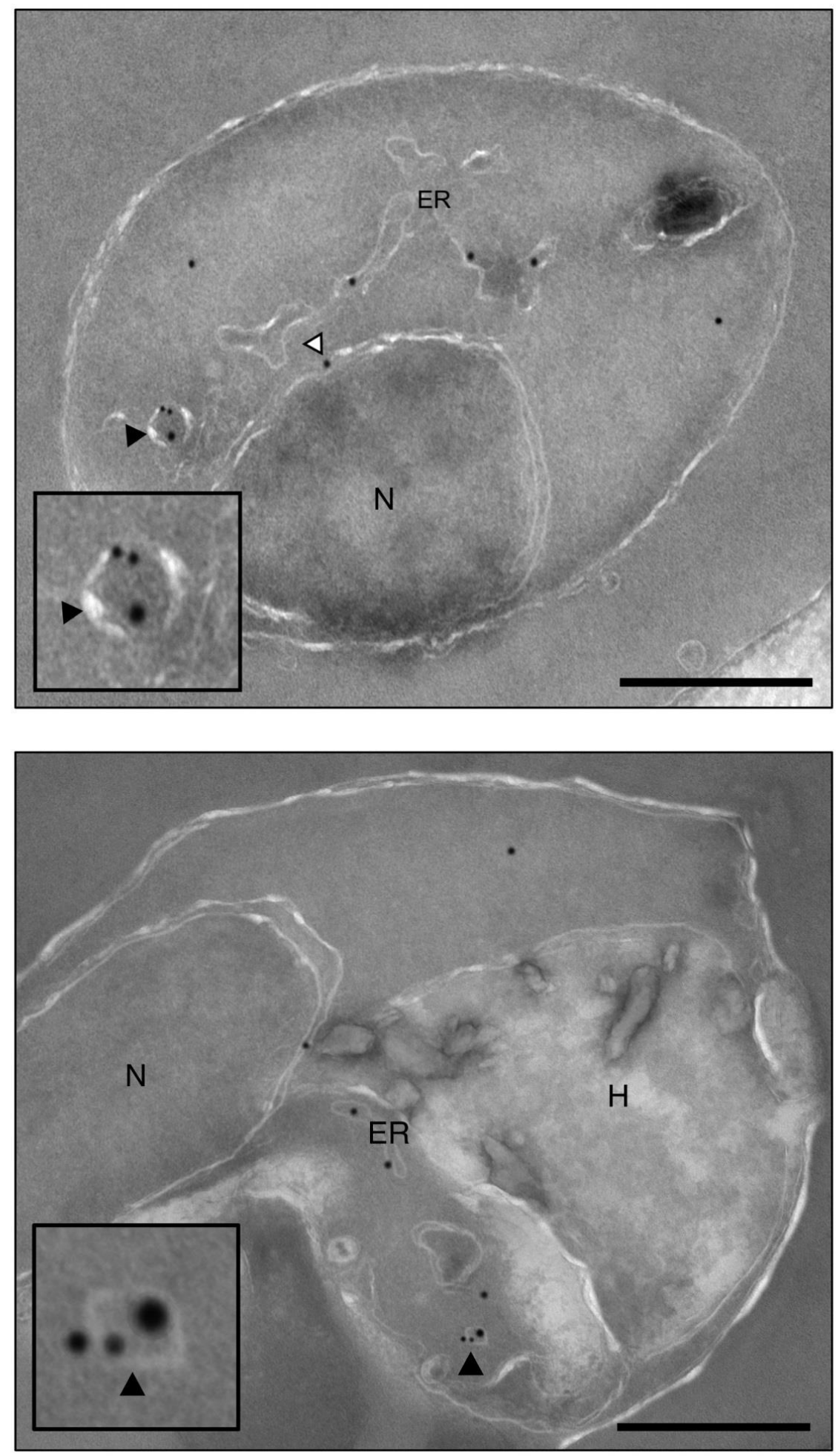

\section{Suppl. Fig. 2. Localisation of AP-2 $\mu-3 x H A$ and Rab5B by immunoelectron microscopy}

Electron micrographs of vesicular colocalisation of AP-2 $\mu-3 x \mathrm{HA}$ (18 nm gold particles) and Rab5B (12 $\mathrm{nm}$ gold particles) in developing trophozoites. N: nucleus; ER: endoplasmic reticulum; $\mathrm{H}$ : haemozoin; white arrowhead: AP- $2 \mu$ at the nuclear membrane; black arrowhead: vesicles co-labelled for both proteins.

Scale bar: $500 \mathrm{~nm}$. 


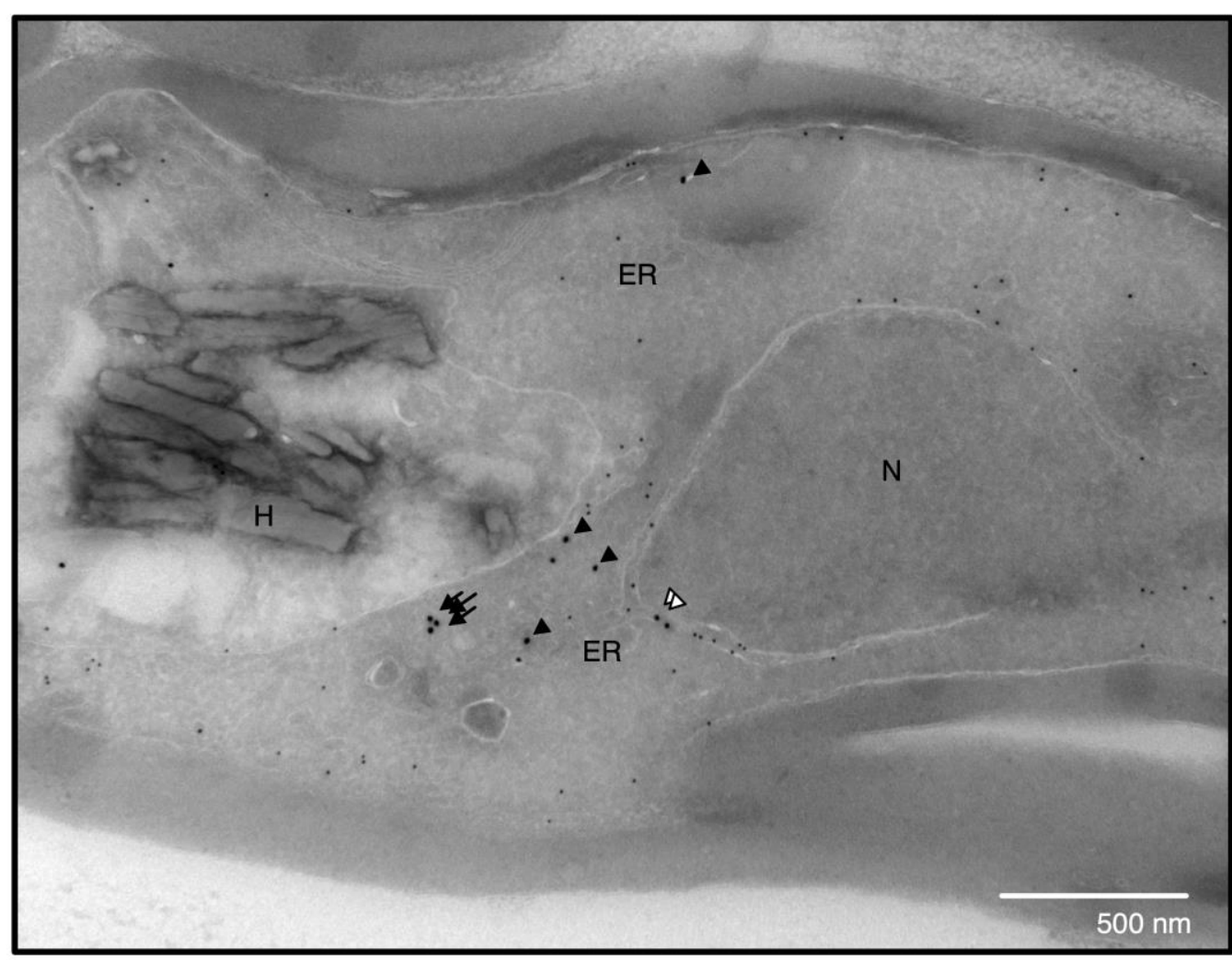

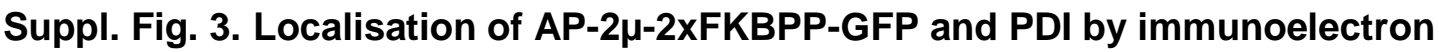 microscopy}

Electron micrographs of vesicular colocalisation of AP-2 $\mu$-2xFKBP-GFP (18 nm gold particles) and PDI (12 nm gold particles) in developing trophozoites. $\mathrm{N}$ : nucleus; ER: endoplasmic reticulum; $\mathrm{H}$ : haemozoin; white arrowhead: AP- $2 \mu$ at the nuclear membrane; black arrow: AP- $2 \mu$ in vesicles; black arrowhead: $A P-2 \mu$ at the ER.

Scale bar: 500 nm. 


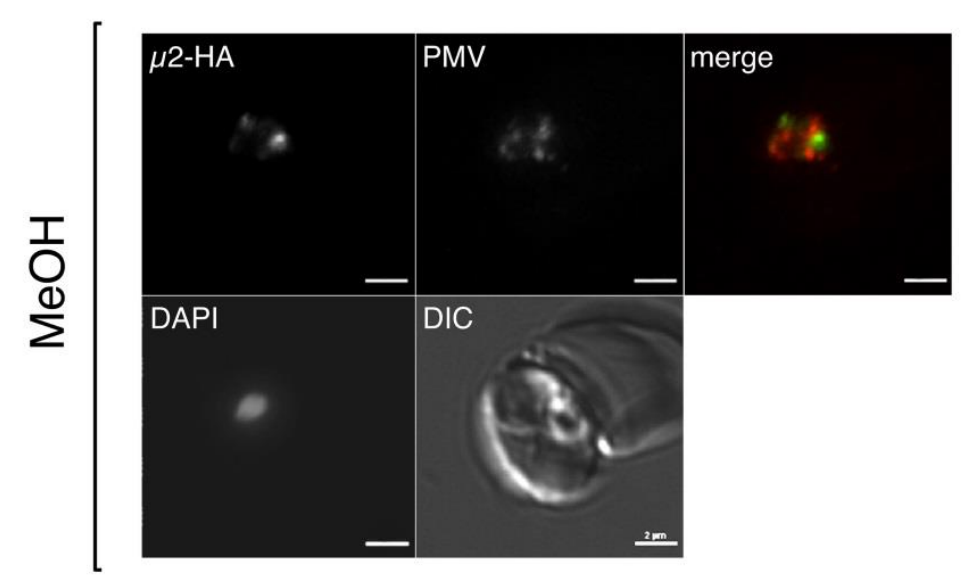

$$
P C C=0.60 \pm 0.07
$$

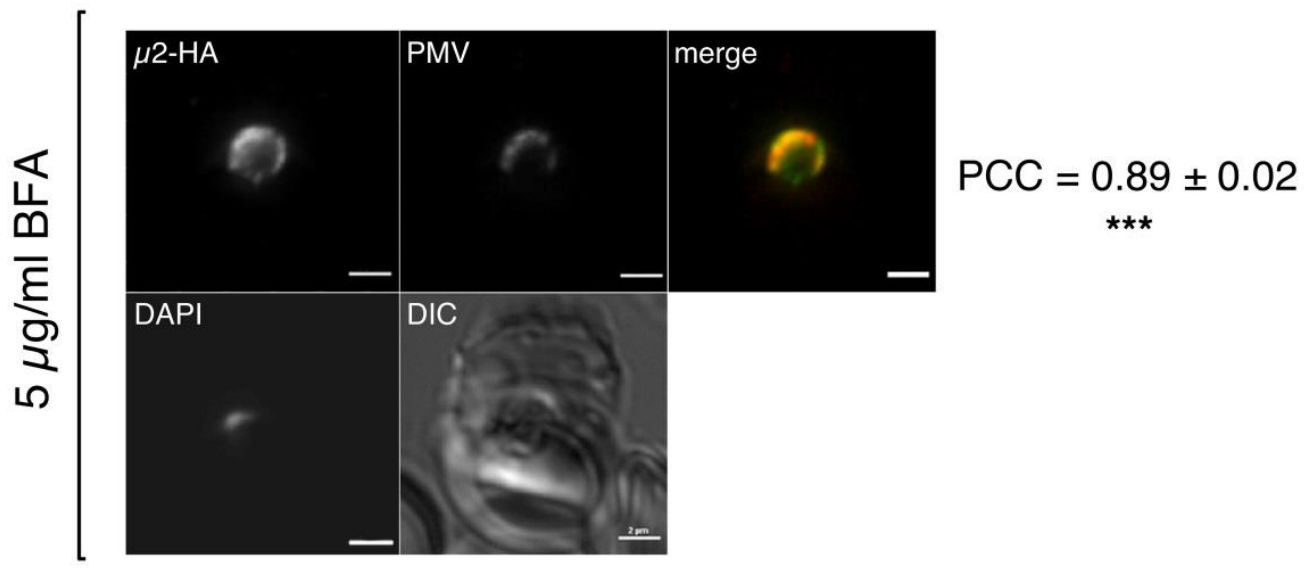

\section{Suppl. Fig. 4. Impact of BFA on localisation of AP-2 $\mu-3 x H A$}

Treatment of synchronised ring-stage parasite cultures with $5 \mu \mathrm{g} / \mathrm{ml} \mathrm{BFA}$ or equivalent methanol solvent for $16 \mathrm{~h}$ and immune-stained for AP- $2 \mu$ (false-coloured green) and plasmepsin V (PMV; red). Cells were fixed and stained in suspension and mounted onto coverslips. Pearson's Correlation Coefficients (PCC) between indirect AP- $2 \mu$ and PMV signals were calculated using Nikon AR Analysis software. Mean of at least 20 cells with standard deviation is shown. PCC were significantly different $\left({ }^{* * *}, \mathrm{P}<0.005\right)$ using a Student's $t$-test. Scale: $2 \mu \mathrm{m}$. 


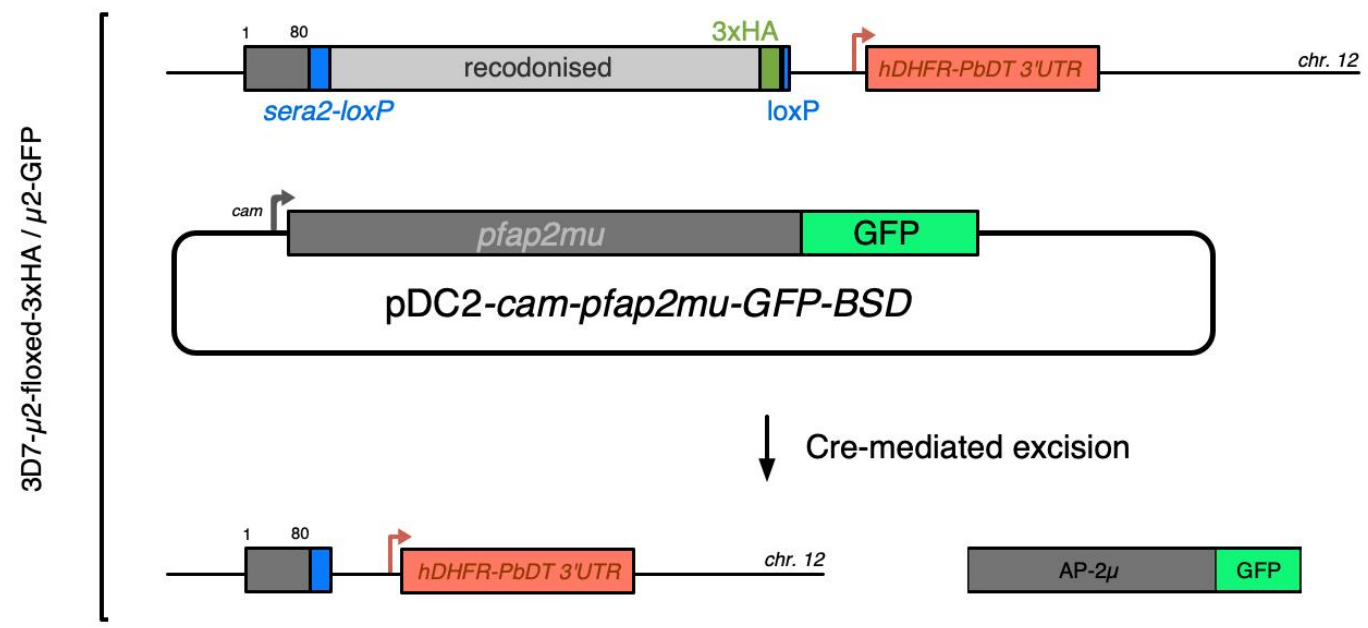

\section{Suppl. Fig. 5 Schematic of episomal complementation of AP-2 $\mu$ knockout}

The floxed AP-2 $\mu$-3xHA- and DiCre-expressing parasite line 3D7- $\mu 2$-floxed-3xHA was transfected with a plasmid that constitutively expresses $\mu 2$-GFP under the cam promoter (pDC2-cam-pfap2muGFP-BSD). These cells were maintained on $2.5 \mu \mathrm{g} / \mathrm{ml}$ blasticidin-S (BSD). Upon addition of rapamycin, split Cre recombinase dimerises and excises the endogenous pfap2mu locus on chromosome 12. Parasites still express $\mu 2$-GFP via the pDC2 episome. 


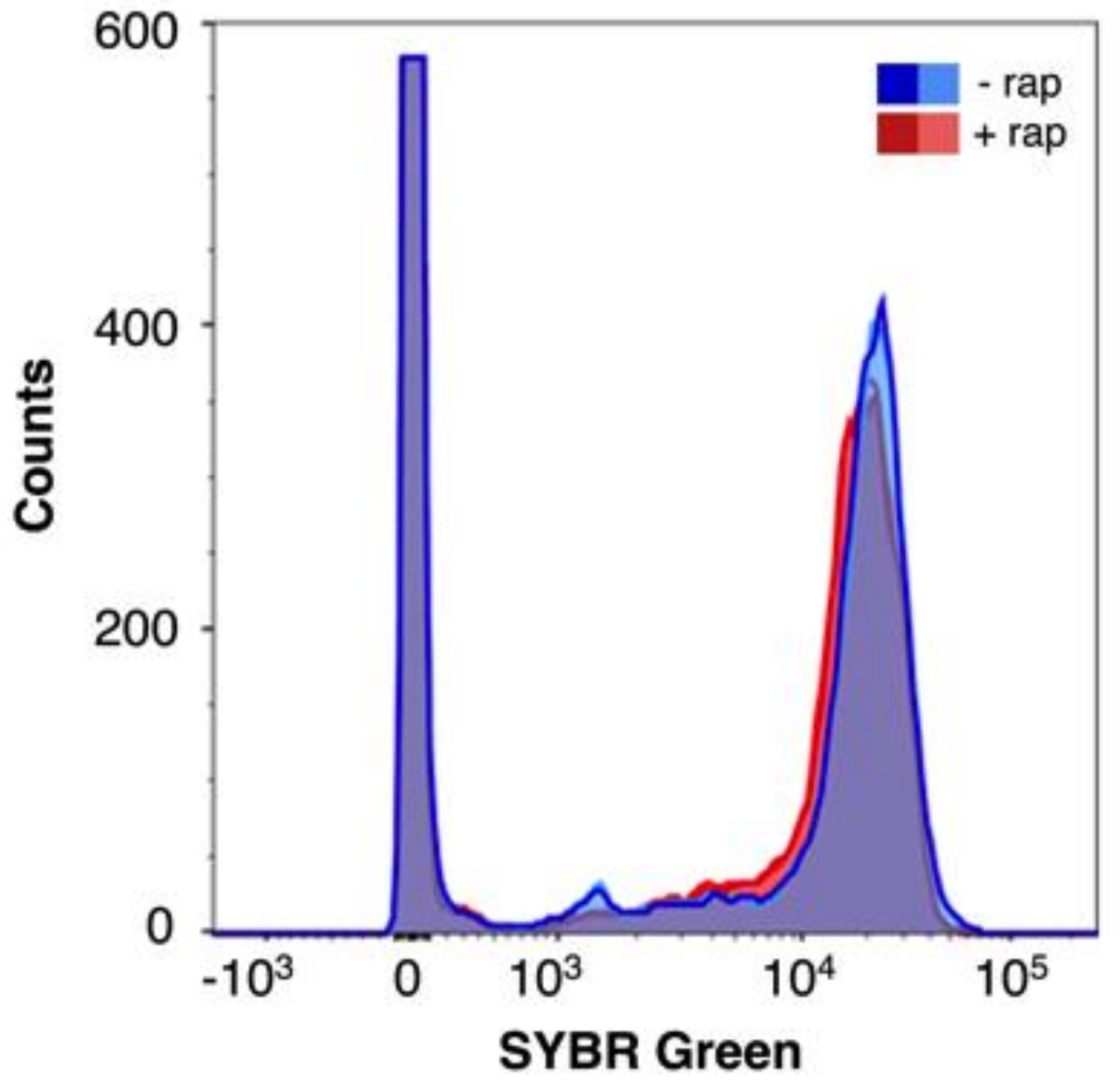

Suppl. Fig. 6 AP-2 $\mu$-KO schizonts have similar nucleic acid content to wild-type schizonts

Representative histogram comparing DNA/RNA content in wild-type (-rap, blue) and AP-2 $\mu-K O$ (+rap, red) schizonts. Nucleic acid was stained using SYBR Green, and SYBR Green signal was detected in live cells by FACS. Rap- parasites were egress-blocked by treatment with the reversible PKG inhibitor Compound 2. 
bioRxiv preprint doi: https://doi.org/10.1101/621078; this version posted April 30, 2019. The copyright holder for this preprint (which was not certified by peer review) is the author/funder, who has granted bioRxiv a license to display the preprint in perpetuity. It is made available under aCC-BY-NC-ND 4.0 International license.
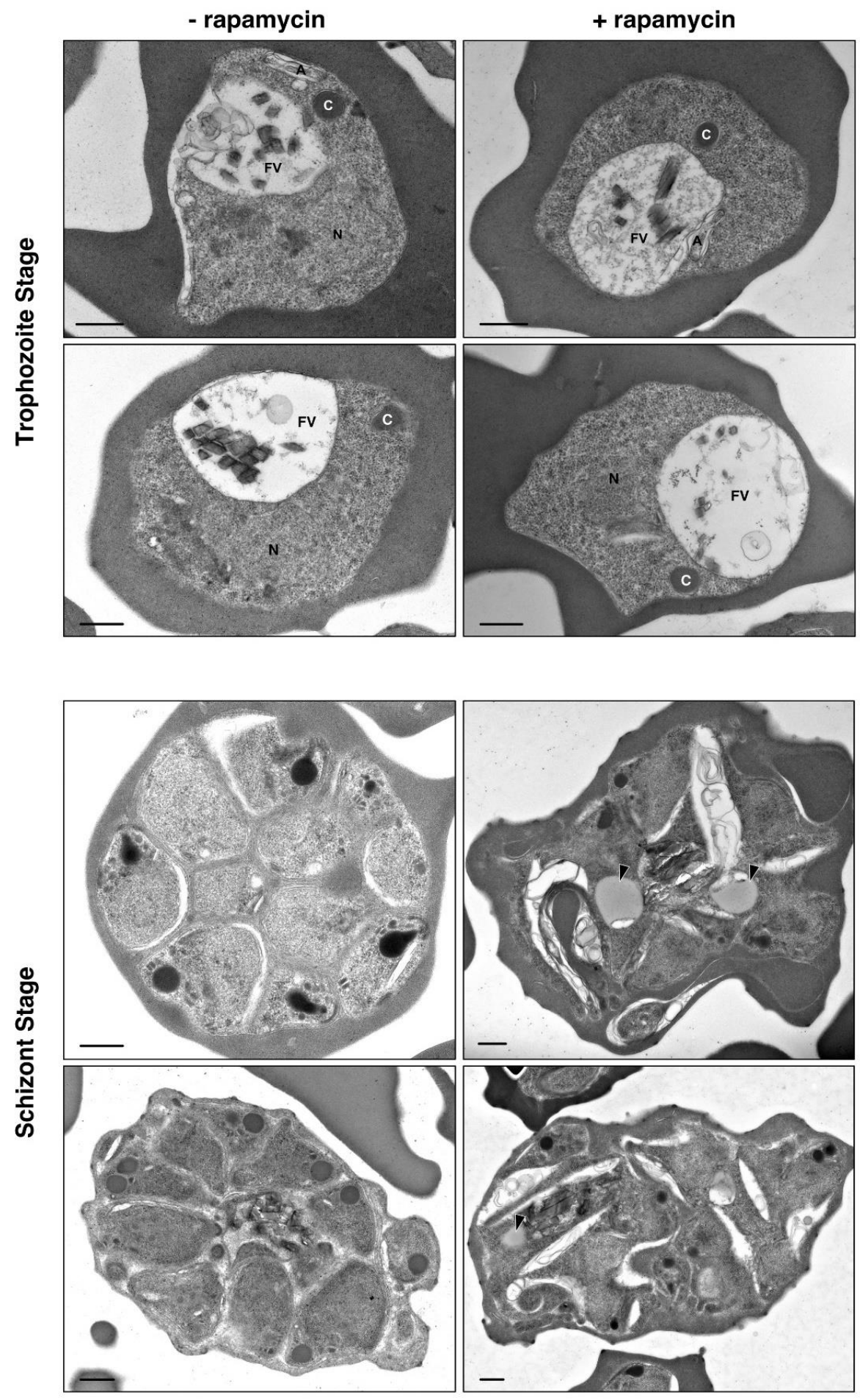

\section{Suppl. Fig. 7. Impact of AP-2 $\mu$ KO on trophozoite and schizont maturation and morphology}

Electron micrographs examining the morphology of wild-type (-rapamycin) and AP-2 $\mu$-KO (+rapamycin) trophozoites (top panel) and schizonts (bottom panel). Two representative micrographs are shown for each cell type. Rapamycin or equivalent DMSO was added to synchronous ring-stage parasites for $1 \mathrm{~h}$ and parasites were fixed for imaging in the same development cycle. 300 schizonts from each treatment were systematically enumerated for key features (see main text). Black arrowheads indicate accumulated lipid bodies in AP- $2 \mu$-KO schizonts. Labels used in trophozoite micrographs N: nucleus; FV: food (digestive) vacuole; C: cytostome; A: apicoplast. 
bioRxiv preprint doi: https://doi.org/10.1101/621078; this version posted April 30, 2019. The copyright holder for this preprint (which was not certified by peer review) is the author/funder, who has granted bioRxiv a license to display the preprint in perpetuity. It is made available under aCC-BY-NC-ND 4.0 International license.
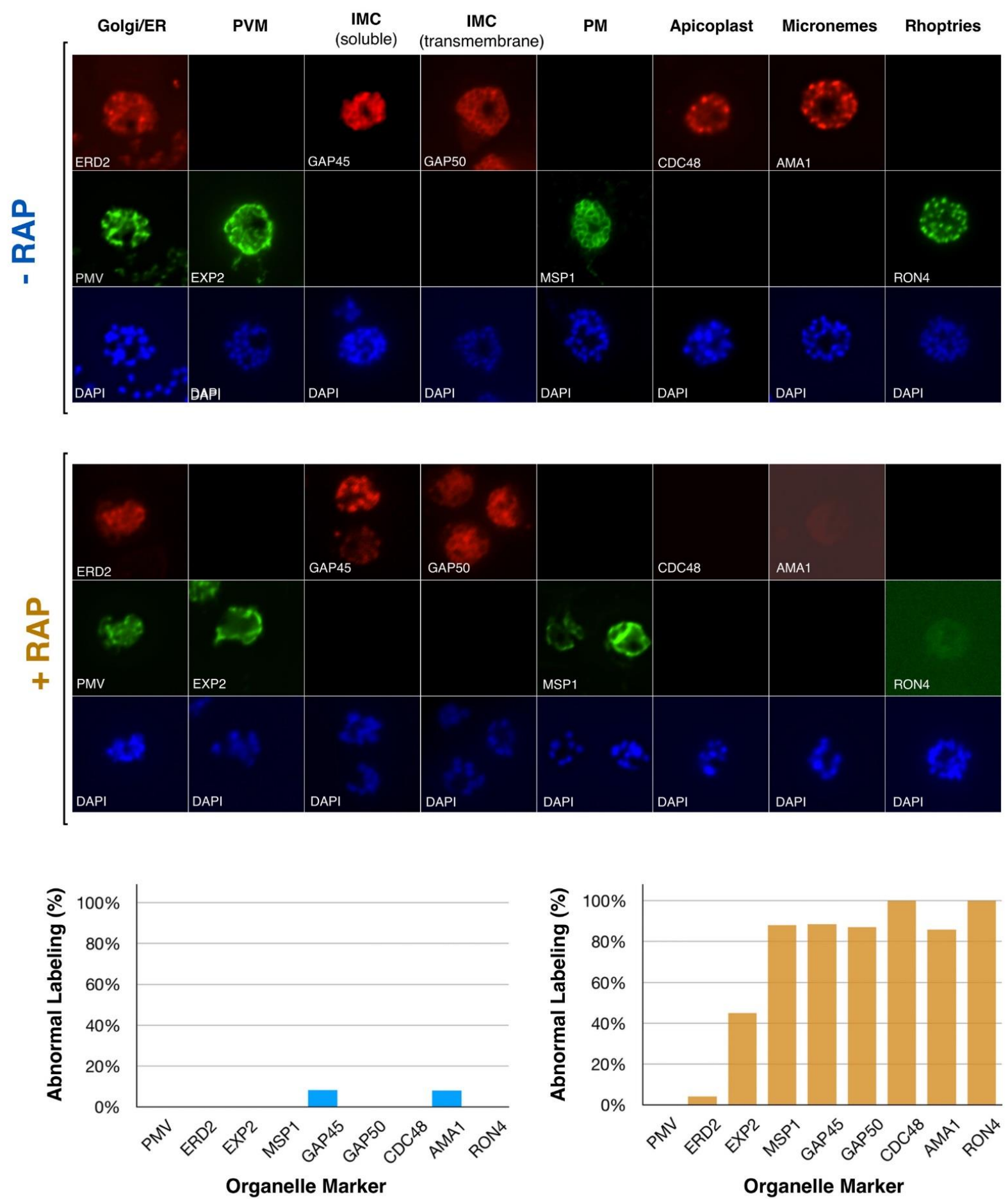

\section{Suppl. Fig. 8. AP-2 $\mu-\mathrm{KO}$ severely disrupts schizont maturation}

Antibodies against the Golgi apparatus (ERD2), ER (PMV), PVM (EXP2), IMC (GAP45, GAP50), PM (MSP1), apicoplast (CDC48), micronemes (AMA1), and rhoptries (RON4) were used to stain egressblocked wild type (-RAP) or $\mu 2-K O$ (+RAP) schizonts. Top panel shows representative IFAs for each organelle marker. Abnormal labelling was quantitated relative to the staining observed in the majority of wild type schizonts (lower panel; left, rap-; right, rap+): ERD2, PMV, CDC48: discrete punctate staining corresponding to each nucleus; EXP2: contiguous, circular, peripheral membrane staining; GAP45, GAP50, MSP1: distinct, circular grape-like staining surrounding each daughter nucleus; AMA1, RON4: discrete, apical punctate spots corresponding to each nucleus.

At least 100 cells were scored for each marker.

IMC: inner membrane complex; PM: plasma membrane; PVM: parasitophorous vacuolar membrane 


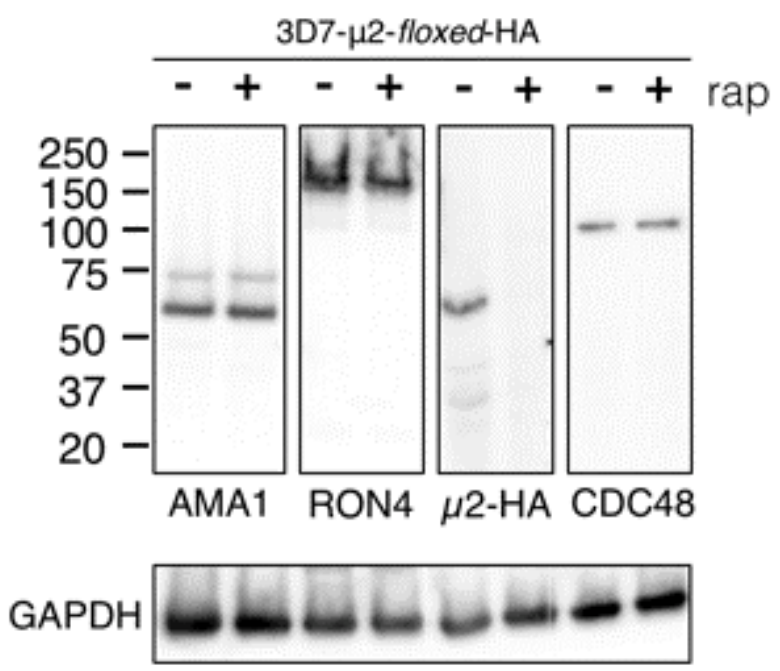

\section{Suppl. Fig. 9. Organelle markers are mislocalised by AP-2 $\mu$ KO}

Antibodies against RON4, AMA1, and CDC48, markers of the rhoptries, micronemes, and apicoplast, failed to stain schizonts lacking $\mu 2$ (Suppl. Figure 4). Western blot analysis of whole-cell lysates prepared from wild type and $\mu 2-\mathrm{KO}$ schizonts confirms the overall cellular abundance of these factors is not affected by $\mu 2-\mathrm{KO}$. 
bioRxiv preprint doi: https://doi org/10.1101/621078; this version posted April 30 2019. The copyright holder for this preprint (which was not certified by peer review) is the author/funder, who has granted bioRxiv a license to display the preprint in perpetuity. It is made available under aCC-BY-NC-ND 4.0 International license.

\begin{tabular}{|rcc|}
\hline & U2-3 $\mathbf{K A}$ & U2-GF \\
\hline Structure & Localisation & Localisation \\
\hline Nuclear Lamina/ER & $73.8 \%$ & $85.2 \%$ \\
DV & $5.8 \%$ & $4.3 \%$ \\
Tubular ER extension/Golgi & $93.6 \%$ & $87.6 \%$ \\
Periphery & $4.2 \%$ & $3.9 \%$ \\
Vesicles & $37.9 \%$ & $30.0 \%$ \\
Cytoplasmic (non-membranous) & $7.6 \%$ & $8.0 \%$ \\
\hline
\end{tabular}

Suppl. Table 1. Quantitation of distribution of gold labels in immunoelectron micrographs 


\begin{tabular}{|ll|}
\hline Primer Name & \multicolumn{1}{c|}{ Sequence } \\
P1 & $5^{\prime}$ - AAGACTGTCAAATGTAAAAGACC \\
P2 & $5^{\prime}$ - CTCATGTAAAACAAAAAGTGAGG \\
P3 & $5^{\prime}$ - CCATAGGCAAAACTGAATT \\
P4 & $5^{\prime}$ - GTCTGATCATAAACATAATATATAATACATAGAAC \\
P5 & $5^{\prime}$ - TITITTCTTCCCACATTTCGAA \\
\hline
\end{tabular}

Suppl. Table 2. Primers used to screen transgenic lines described in this study 
bioRxiv preprint doi: https://doi.org/10.1101/621078; this version posted April 30, 2019. The copyright holder for this preprint (which was not certified by peer review) is the author/funder, who has granted bioRxiv a license to display the preprint in perpetuity. It is made available under aCC-BY-NC-ND 4.0 International license.

\begin{tabular}{|c|c|c|c|}
\hline Protein ID & Protein Name & $\begin{array}{c}\text { Average-Enrich. } \\
\text { Triton }\end{array}$ & $\begin{array}{c}\text { Average-Enrich. } \\
\text { CHAPS }\end{array}$ \\
\hline PF3D7_1147300 & Conserved Plasmodium protein, unknown function & $\infty$ & ND \\
\hline PF3D7_1459000 & ATP-dependent RNA helicase DBP5 & $\infty$ & ND \\
\hline PF3D7_1251600 & Conserved Plasmodium protein, unknown function & $\infty$ & ND \\
\hline PF3D7_0720100 & Small subunit rRNA processing protein, putative & $\infty$ & ND \\
\hline PF3D7_1123400 & Translation elongation factor EF-1, subunit a & $\infty$ & ND \\
\hline PF3D7_1027400 & DNA-directed RNA polymerase II subunit RPB7 & $\infty$ & ND \\
\hline PF3D7_0208700 & Conserved Plasmodium protein, unknown function & $\infty$ & ND \\
\hline PF3D7_1471400 & Diacylglycerol kinase & $\infty$ & ND \\
\hline PF3D7_0611700 & $60 S$ ribosomal protein L39 & $\infty$ & ND \\
\hline PF3D7_1138800 & WD repeat-containing protein & $\infty$ & $\infty$ \\
\hline PF3D7_1434300 & Hsp70/Hsp90 organizing protein & $\infty$ & $\infty$ \\
\hline PF3D7_1218300 & AP-2 complex subunit mu & 28.65 & 341.39 \\
\hline PF3D7_1114200 & GTPase-activating protein, putative & 21.83 & $\infty$ \\
\hline PF3D7_0617100 & AP-2 complex subunit alpha & 21.01 & 240.76 \\
\hline PF3D7_1022600 & Kelch protein $\mathrm{K} 10$ & 19.82 & 0.07 \\
\hline PF3D7_0217300 & AP-2 complex subunit sigma & 17.10 & $\infty$ \\
\hline PF3D7_1461300 & $40 S$ ribosomal protein $\mathrm{S} 28 \mathrm{e}$ & 9.75 & ND \\
\hline PF3D7_0710400 & DNA repair protein RAD14 & 8.44 & ND \\
\hline PF3D7_0802000 & Glutamate dehydrogenase & 8.33 & 5.06 \\
\hline PF3D7_1137400 & UVB-resistance protein UVR8 homologue & 7.54 & ND \\
\hline PF3D7_1205900 & Conserved protein, unknown function & 7.45 & $\infty$ \\
\hline PF3D7_1402500 & Ribosomal protein S27a & 6.60 & $\infty$ \\
\hline PF3D7_1470700 & Conserved Plasmodium protein & 6.60 & ND \\
\hline PF3D7_1230900 & Serine/threonine protein kinase RIO1 & 6.30 & $\infty$ \\
\hline PF3D7_0508600 & Conserved Plasmodium protein, unknown function & 6.16 & ND \\
\hline PF3D7_0321100 & Conserved Plasmodium protein, unknown function & 5.90 & ND \\
\hline PF3D7_0813000 & Conserved Plasmodium protein, unknown function & 5.19 & ND \\
\hline PF3D7_0801800 & Mannose-6-phosphate isomerase & 5.15 & ND \\
\hline PF3D7_0529500 & Cell cycle regulator protein & 5.07 & ND \\
\hline PF3D7_0212300 & Peptide chain release factor subunit 1 & 4.93 & ND \\
\hline PF3D7_0205800 & $\mathrm{PH}$ domain-containing protein & 4.74 & ND \\
\hline PF3D7_0102200 & Ring-infected erythrocyte surface antigen & 4.66 & ND \\
\hline PF3D7_1149200 & Ring-infected erythrocyte surface antigen & 4.62 & ND \\
\hline PF3D7_0303300 & $\begin{array}{l}\text { DNA-directed RNA polymerases I, II, and III subunit } \\
\text { RPABC2 }\end{array}$ & 4.45 & ND \\
\hline PF3D7_0304200 & EH domain-containing protein (EPS15) & 4.43 & $\infty$ \\
\hline PF3D7_1111000 & tRNA m5C-methyltransferase & 4.23 & ND \\
\hline PF3D7_1109400 & Essential nuclear protein 1 & 4.18 & ND \\
\hline PF3D7_0106700 & Small ribosomal subunit assembling AARP2 protein & 4.18 & ND \\
\hline PF3D7_1404500 & rRNA biogenesis protein RRP5 & 4.09 & ND \\
\hline PF3D7_1205700 & Targeted glyoxalase II & 3.90 & ND \\
\hline PF3D7_1104400 & Thioredoxin & 3.85 & ND \\
\hline
\end{tabular}


bioRxiv preprint doi: https://doi org/10.1101/621078; this version posted April 30,2019 . The copyright holder for this preprint (which was not certified by peer review) is the author/funder, who has granted bioRxiv a license to display the preprint in perpetuity. It is made available under aCC-BY-NC-ND 4.0 International license.

\begin{tabular}{|c|c|c|c|}
\hline PF3D7_1451900 & Ribosome biogenesis protein TSR1 & 3.83 & $\infty$ \\
\hline PF3D7_0731300 & $\begin{array}{l}\text { Plasmodium exported protein (PHISTb), unknown } \\
\text { function }\end{array}$ & 3.83 & ND \\
\hline PF3D7_0813600 & Translation initiation factor SUI1 & 3.70 & ND \\
\hline PF3D7_0416400 & Histone acetyltransferase & 3.70 & ND \\
\hline PF3D7_0803100 & U3 small nucleolar RNA-associated protein 14 & 3.65 & ND \\
\hline PF3D7_1471000 & RNA 3-terminal phosphate cyclase-like protein & 3.61 & ND \\
\hline PF3D7_0522300 & 18S rRNA (guanine-N(7))-methyltransferase & 3.54 & ND \\
\hline PF3D7_0708500 & Heat shock protein 86 family protein & 3.52 & ND \\
\hline PF3D7_0528100 & AP-1 complex subunit beta & 3.49 & 26.11 \\
\hline PF3D7_1129100 & Parasitophorous vacuolar protein 1 & 3.47 & 11.66 \\
\hline PF3D7_0722000 & Conserved Plasmodium protein, unknown function & 3.45 & $\infty$ \\
\hline PF3D7_1010600 & Eukaryotic translation initiation factor 2 subunit & 3.41 & ND \\
\hline PF3D7_0408500 & Flap endonuclease 1 & 3.41 & $\infty$ \\
\hline PF3D7_1108000 & IWS1-like protein & 3.39 & ND \\
\hline PF3D7_0106000 & Conserved Plasmodium protein & 3.30 & ND \\
\hline PF3D7_0417800 & Cdc2-related protein kinase 1 & 3.19 & ND \\
\hline PF3D7_0903400 & ATP-dependent RNA helicase DDX60 & 3.16 & ND \\
\hline PF3D7_1033300 & Conserved Plasmodium protein, unknown function & 3.09 & ND \\
\hline PF3D7_0907600 & Translation initiation factor SUI1 & 3.08 & ND \\
\hline PF3D7_0205600 & Conserved Plasmodium protein & 3.04 & ND \\
\hline PF3D7_1407500 & Multifunctional methyltransferase subunit TRM & 3.04 & $\infty$ \\
\hline PF3D7_0926900 & Replication termination factor & 3.00 & ND \\
\hline PF3D7_0903400 & RNA export binding protein & 1.73 & $\infty$ \\
\hline PF3D7_1033300 & peroxiredoxin (oxidative stress defense) & 1.63 & 159.73 \\
\hline PF3D7_0907600 & Parasitophorous vacuolar protein 2 & 1.30 & $\infty$ \\
\hline PF3D7_0205600 & 60S Ribosomal Protein L23 & 0.83 & 24.54 \\
\hline PF3D7_1407500 & 60S Ribosomal Protein L26 & 0.81 & 15.67 \\
\hline PF3D7_0926900 & AP2 domain transcription factor AP2-G (nuclear) & 0.53 & 27.51 \\
\hline PF3D7_1341300 & 60S Ribosomal Protein L18 & 0.49 & 15.35 \\
\hline PF3D7 1237200 & Conserved Plasmodium protein, unknown function & 0.46 & 10.11 \\
\hline
\end{tabular}

\section{Supplementary Table 3. Extended IP-MS interactome of AP-2 $\mu$}

Factors identified with greater than 3-fold enrichment in HA pulldown in either condition compared to control pulldowns with statistical difference between HA and control pulldowns greater than 0 and at least 2 peptides per protein. $\infty$ indicates that no peptides were detected in the control pulldown; ND indicates protein was not identified in either the control or HA pulldown. 
bioRxiv preprint doi: https://doi.org/10.1101/621078; this version posted April 30, 2019. The copyright holder for this preprint (which was not certified by peer review) is the author/funder, who has granted bioRxiv a license to display the preprint in perpetuity. It is made available under aCC-BY-NC-ND 4.0 International license.

\begin{tabular}{|c|c|c|c|c|c|}
\hline Protein ID & Protein Name & $\begin{array}{l}\text { Average-LFQ } \\
\text { wt }(\mathrm{N}=3)\end{array}$ & $\begin{array}{l}\text { Average-LFQ } \\
\text { GFP }(\mathrm{N}=4)\end{array}$ & Enrichment & $-\log (P)$ \\
\hline PF3D7_1421000 & DIX domain-containing protein & ND & $9.42 \mathrm{E}+08$ & $\infty$ & 3.34 \\
\hline PF3D7_1411300 & DnaJ protein & ND & $7.14 \mathrm{E}+08$ & $\infty$ & 5.05 \\
\hline PF3D7_0903400 & ATP-dependent RNA helicase DDX60 & ND & $5.67 \mathrm{E}+08$ & $\infty$ & 0.25 \\
\hline PF3D7_API0180 & Apicoplast ribosomal protein L16 & ND & $1.30 \mathrm{E}+08$ & $\infty$ & 0.62 \\
\hline PF3D7_0815800 & Vacuolar protein sorting-associated protein 9 & ND & $1.25 \mathrm{E}+08$ & $\infty$ & 2.26 \\
\hline PF3D7_1037600 & $\begin{array}{l}\text { TFIlH basal transcription factor complex helicase XPB } \\
\text { subunit }\end{array}$ & ND & $7.32 \mathrm{E}+07$ & $\infty$ & 0.27 \\
\hline PF3D7_0806800 & V-type proton ATPase subunit A & ND & $6.37 \mathrm{E}+07$ & $\infty$ & 2.09 \\
\hline PF3D7_0202600 & Nucleic acid binding protein & ND & $6.27 \mathrm{E}+07$ & $\infty$ & 0.40 \\
\hline PF3D7_1210100 & Syntaxin, Qa-SNARE family & ND & $5.22 \mathrm{E}+07$ & $\infty$ & 0.46 \\
\hline PF3D7_0907700 & Proteasome activator 28 subunit beta & ND & $4.51 \mathrm{E}+07$ & $\infty$ & 0.12 \\
\hline PF3D7_1458000 & Cysteine proteinase falcipain 1 & ND & $3.84 \mathrm{E}+07$ & $\infty$ & 0.64 \\
\hline PF3D7_0316500 & Kinetochore protein NUF2 & ND & $3.15 \mathrm{E}+07$ & $\infty$ & 0.01 \\
\hline PF3D7_0301700 & Plasmodium exported protein, unknown function & ND & $3.12 \mathrm{E}+07$ & $\infty$ & 0.49 \\
\hline PF3D7_0314100 & Vesicle transport v-SNARE protein & ND & $2.95 \mathrm{E}+07$ & $\infty$ & 0.60 \\
\hline PF3D7_1006700 & Conserved Plasmodium protein, unknown function & ND & $2.94 \mathrm{E}+07$ & $\infty$ & 0.06 \\
\hline PF3D7_1118100 & AP-1 complex subunit sigma & ND & $2.90 \mathrm{E}+07$ & $\infty$ & 0.15 \\
\hline PF3D7_0802400 & Conserved Plasmodium protein, unknown function & ND & $2.89 \mathrm{E}+07$ & $\infty$ & 0.00 \\
\hline PF3D7_0306100 & Conserved Plasmodium protein, unknown function & ND & $2.79 \mathrm{E}+07$ & $\infty$ & 0.21 \\
\hline PF3D7_0820500 & Protein transport protein YIF1 & ND & $2.71 \mathrm{E}+07$ & $\infty$ & 0.76 \\
\hline PF3D7_0320100 & Protein transport protein SEC22 & ND & $2.51 \mathrm{E}+07$ & $\infty$ & 0.02 \\
\hline PF3D7_1328100 & Proteasome subunit beta type- 7 & ND & $2.36 \mathrm{E}+07$ & $\infty$ & 0.41 \\
\hline PF3D7_1110200 & Pre-mRNA-processing factor 6 & ND & $2.21 \mathrm{E}+07$ & $\infty$ & 0.02 \\
\hline PF3D7_0914900 & BSD-domain protein & ND & $2.10 \mathrm{E}+07$ & $\infty$ & 0.26 \\
\hline PF3D7_0103200 & Nucleoside transporter 4 & ND & $1.89 \mathrm{E}+07$ & $\infty$ & 0.48 \\
\hline PF3D7_0529000 & Conserved Plasmodium protein, unknown function & ND & $1.86 \mathrm{E}+07$ & $\infty$ & 0.62 \\
\hline PF3D7_0205500 & DNA-directed RNA polymerase II $16 \mathrm{kDa}$ subunit & ND & $1.86 \mathrm{E}+07$ & $\infty$ & 0.03 \\
\hline PF3D7_1329500 & Conserved protein, unknown function & ND & $1.58 \mathrm{E}+07$ & $\infty$ & 0.17 \\
\hline PF3D7_1464700 & ATP synthase (C/AC39) subunit & ND & $1.23 \mathrm{E}+07$ & $\infty$ & 0.15 \\
\hline PF3D7_1004400 & RNA-binding protein & ND & $1.22 \mathrm{E}+07$ & $\infty$ & 0.37 \\
\hline PF3D7_0931800 & Proteasome subunit beta type- 6 & ND & $9.31 \mathrm{E}+06$ & $\infty$ & 0.07 \\
\hline PF3D7_1419400 & $\begin{array}{l}\text { Conserved Plasmodium membrane protein, unknown } \\
\text { function }\end{array}$ & ND & $9.13 \mathrm{E}+06$ & $\infty$ & 0.12 \\
\hline PF3D7_1435500 & Clathrin light chain & $7.17 \mathrm{E}+07$ & $2.19 \mathrm{E}+09$ & 30.56 & 2.74 \\
\hline PF3D7_1219100 & Clathrin heavy chain & $3.07 \mathrm{E}+09$ & $6.87 \mathrm{E}+10$ & 22.38 & 2.81 \\
\hline PF3D7_1307700 & TOM1-like protein & $3.32 \mathrm{E}+07$ & $6.91 \mathrm{E}+08$ & 20.81 & 2.78 \\
\hline PF3D7_1459600 & Conserved Plasmodium protein, unknown function & $1.17 \mathrm{E}+08$ & $2.33 \mathrm{E}+09$ & 19.89 & 2.31 \\
\hline PF3D7_1432800 & HP12 protein homolog & $1.72 \mathrm{E}+07$ & $2.14 \mathrm{E}+08$ & 12.40 & 1.63 \\
\hline PF3D7_1311400 & AP-1 complex subunit mu-1 & $2.93 \mathrm{E}+07$ & $3.18 \mathrm{E}+08$ & 10.85 & 2.42 \\
\hline PF3D7_1353200 & Membrane associated histidine-rich protein & $5.61 \mathrm{E}+06$ & $5.30 \mathrm{E}+07$ & 9.45 & 0.35 \\
\hline PF3D7_1016300 & GBP130 protein & $1.75 \mathrm{E}+07$ & $1.56 \mathrm{E}+08$ & 8.92 & 2.38 \\
\hline PF3D7_1455500 & AP-1 complex subunit gamma & $7.43 \mathrm{E}+07$ & $6.48 \mathrm{E}+08$ & 8.72 & 2.27 \\
\hline PF3D7_1308200 & Carbamoyl phosphate synthetase & $2.60 \mathrm{E}+08$ & $1.71 \mathrm{E}+09$ & 6.57 & 3.07 \\
\hline
\end{tabular}




\begin{tabular}{|c|c|c|c|c|c|}
\hline PF3D7_1451800 & Sortilin & $6.96 \mathrm{E}+08$ & 4.47E+09 & 6.42 & 1.51 \\
\hline PF3D7_1408700 & Conserved protein, unknown function & $3.24 \mathrm{E}+08$ & $1.99 \mathrm{E}+09$ & 6.15 & 1.33 \\
\hline PF3D7_1214900 & Conserved protein, unknown function & $2.96 \mathrm{E}+07$ & $1.71 \mathrm{E}+08$ & 5.78 & 1.93 \\
\hline PF3D7_0704400 & Phosphoinositide-binding protein & $4.90 \mathrm{E}+07$ & $2.72 \mathrm{E}+08$ & 5.55 & 1.58 \\
\hline PF3D7_0102200 & Ring-infected erythrocyte surface antigen & $5.42 \mathrm{E}+07$ & $2.64 \mathrm{E}+08$ & 4.87 & 2.16 \\
\hline PF3D7_0528100 & AP-1 complex subunit beta, putative / tr & $1.25 \mathrm{E}+08$ & $5.69 \mathrm{E}+08$ & 4.56 & 2.06 \\
\hline PF3D7_1215900 & Serpentine receptor & $2.48 \mathrm{E}+07$ & $1.11 \mathrm{E}+08$ & 4.47 & 1.27 \\
\hline PF3D7_0530100 & SNARE protein & $1.38 \mathrm{E}+07$ & $5.95 \mathrm{E}+07$ & 4.32 & 1.18 \\
\hline PF3D7_0936000 & Ring-exported protein 2 & $1.76 \mathrm{E}+07$ & $6.67 \mathrm{E}+07$ & 3.80 & 0.90 \\
\hline PF3D7_0103900 & Parasite-infected erythrocyte surface protein & $2.84 \mathrm{E}+07$ & $1.04 \mathrm{E}+08$ & 3.65 & 1.28 \\
\hline PF3D7_0412000 & LITAF-like zinc finger protein & $2.06 \mathrm{E}+07$ & $7.26 \mathrm{E}+07$ & 3.52 & 0.36 \\
\hline PF3D7_1330400 & ER lumen protein retaining receptor 1 & $1.01 \mathrm{E}+08$ & $3.52 \mathrm{E}+08$ & 3.50 & 1.26 \\
\hline PF3D7_0716300 & Conserved protein, unknown function & $1.03 \mathrm{E}+08$ & $3.59 \mathrm{E}+08$ & 3.47 & 1.36 \\
\hline PF3D7_1320000 & Golgi protein 1 & $2.77 \mathrm{E}+07$ & $9.49 \mathrm{E}+07$ & 3.42 & 1.22 \\
\hline PF3D7_1359600 & Conserved Plasmodium protein, unknown function & $8.12 \mathrm{E}+08$ & $2.77 \mathrm{E}+09$ & 3.41 & 0.35 \\
\hline PF3D7_1015600 & Heat shock protein 60 & $3.59 \mathrm{E}+07$ & $1.22 \mathrm{E}+08$ & 3.38 & 0.99 \\
\hline PF3D7_1010100 & PI31 domain-containing protein & $2.63 \mathrm{E}+07$ & $8.86 \mathrm{E}+07$ & 3.38 & 1.40 \\
\hline PF3D7_0532100 & Early transcribed membrane protein 5 & $1.01 \mathrm{E}+08$ & $3.36 \mathrm{E}+08$ & 3.32 & 1.08 \\
\hline PF3D7_0936800 & Plasmodium exported protein (PHISTc), unknown function & $3.30 \mathrm{E}+07$ & $1.08 \mathrm{E}+08$ & 3.27 & 1.12 \\
\hline PF3D7_1123500 & Golgi protein 2 & $2.97 \mathrm{E}+07$ & $9.70 \mathrm{E}+07$ & 3.26 & 1.10 \\
\hline PF3D7_0922100 & Ubiquitin-like protein & $2.32 \mathrm{E}+07$ & $7.14 \mathrm{E}+07$ & 3.07 & 0.17 \\
\hline PF3D7_1239700 & ATP-dependent zinc metalloprotease FTSH 1 & $5.34 \mathrm{E}+07$ & $1.60 \mathrm{E}+08$ & 3.00 & 1.18 \\
\hline
\end{tabular}

\section{Supplementary Table 4. Extended IP-MS interactome of clathrin heavy chain}

Factors identified with greater than 3-fold enrichment in GFP pulldowns compared to control pulldowns with statistical difference between GFP and control pulldowns greater than 0 and at least 2 peptides per protein. $\infty$ indicates that no peptides were detected in the control pulldown; ND indicates protein was not identified in either the control or HA pulldown. 